Article

\title{
Rodents as Hosts of Pathogens and Related Zoonotic Disease Risk
}

\author{
Handi Dahmana 1,2 (D), Laurent Granjon ${ }^{3}\left(\mathbb{D}\right.$, Christophe Diagne ${ }^{3}$, Bernard Davoust ${ }^{1,2}$, \\ Florence Fenollar ${ }^{2,4}$ and Oleg Mediannikov ${ }^{1,2, *}$ \\ 1 Aix-Marseille University, IRD, AP-HM, MEPHI, 13005 Marseille, France; \\ handi.dahmana@etu.univ-amu.fr (H.D.); bernard.davoust@gmail.com (B.D.) \\ 2 IHU-Méditerranée Infection, 13005 Marseille, France; florence.fenollar@univ-amu.fr \\ 3 CBGP, IRD, CIRAD, INRA, Montpellier SupAgro, University Montpellier, 34980 Montpellier, France; \\ laurent.granjon@ird.fr (L.G.); chrisdiagne89@hotmail.fr (C.D.) \\ 4 Aix Marseille University, IRD, AP-HM, SSA, VITROME, 13005 Marseille, France \\ * Correspondence: olegusss1@gmail.com; Tel.: +33-(0)4-13-73-24-01; Fax: +33-(0)4-13-73-24-02
}

Received: 10 February 2020; Accepted: 8 March 2020; Published: 10 March 2020

\begin{abstract}
Rodents are known to be reservoir hosts for at least 60 zoonotic diseases and are known to play an important role in their transmission and spread in different ways. We sampled different rodent communities within and around human settlements in Northern Senegal, an area subjected to major environmental transformations associated with global changes. Herein, we conducted an epidemiological study on their bacterial communities. One hundred and seventy-one (171) invasive and native rodents were captured, 50 from outdoor trapping sites and 121 rodents from indoor habitats, consisting of five species. The DNA of thirteen pathogens was successfully screened on the rodents' spleens. We found: $2.3 \%$ of spleens positive to Piroplasmida and amplified one which gave a potentially new species Candidatus "Theileria senegalensis"; 9.35\% of Bartonella spp. and amplified 10, giving three genotypes; 3.5\% of filariasis species; $18.12 \%$ of Anaplasmataceae species and amplified only 5, giving a new potential species Candidatus "Ehrlichia senegalensis"; $2.33 \%$ of Hepatozoon spp.; 3.5\% of Kinetoplastidae spp.; and $15.2 \%$ of Borrelia spp. and amplified 8 belonging all to Borrelia crocidurae. Some of the species of pathogens carried by the rodents of our studied area may be unknown because most of those we have identified are new species. In one bacterial taxon, Anaplasma, a positive correlation between host body mass and infection was found. Overall, male and invasive rodents appeared less infected than female and native ones, respectively.
\end{abstract}

Keywords: pathogens host; zoonotic disease; rodents; Bartonella; Borrelia crocidurae; Anaplasmataceae; Piroplasmida; Hepatozoon

\section{Introduction}

Rodents represent the largest order of living mammals (approximately 2277 known species belonging to 33 families, which is nearly $42 \%$ of the global mammalian biodiversity) and have an almost worldwide distribution (with the exception of the Antarctica and some islands) [1]. They are well adapted to a wide range of habitats [2] and undoubtedly represent the mammals that have most often accompanied humans in their global dispersal. As such, they have had the opportunity to settle where they were introduced and then become invasive with several effects on biodiversity and profound impacts on human activities [1,2]. The current global change context (e.g., land-use change, urbanization) is particularly suitable for the expansion of several rodent species beyond their natural distribution areas, particularly due to their synanthropic affinities [2]. In this respect, the world's urban population is set to rise by 2.1 billion in 2030, which is likely to induce crucial ecological and sanitary changes [3,4], especially those associated with these rodent species [5].

Indeed, rodents are known to be reservoir hosts for at least 60 zoonotic diseases [4], and to play a major role in their transmission and spread in different ways [6,7]. Among the most important diseases 
in terms of public health are salmonellosis, plague, leptospirosis, leishmaniasis, toxoplasmosis, rat-bit fever, taeniasis-like Capillaria hepatica, zoonotic babesiosis, Lassa fever, hemorrhagic fever with renal syndrome (HFRS), and the hantavirus cardiopulmonary syndrome (HCPS), both caused by Hantavirus. In addition, other Arenaviruses are responsible for South American Hemorrhagic Fevers (SAHF) [7-12]. More particularly, rodents may harbor different complex bacteria, such as Mycobacterium tuberculosis and Mycobacterium microti, Escherichia coli, agents of tularemia, tick-borne relapsing fever, bartonellosis, listeriosis, Lyme disease, $\mathrm{Q}$ fever, ehrlichiosis and others [13-15].

In Senegal, many studies documented the sanitary effects of invasive rodents (3). Multiple projects studied the distribution of rodents in Senegal [2,16,17]. More than 30 rodents species have been recorded in this country, belonging to Gliridae, Dipodidae, and Muridae (Gerbilinae, Murinae, and Dendromurinae) $[17,18]$. Simultaneously, follow-ups are usually carried out on certain pathogens potentially transmitted by rodent populations, particularly to humans. This allowed the evaluation of rodent-associated health risk [17]. In addition, new potential bacteria, whose pathogenicity remains unknown, continue to be isolated from rodents [19]. A recent study conducted in Senegal has shown the difficulty in predicting the relationship between biodiversity and the risks of transmission of pathogens, especially zoonotic ones, and recommends some prevention strategies based on the global monitoring of pathogens, but especially the precise characterization of the potential zoonotic agents [20].

In the frame of various projects on rodents and their bacterial pathogens in Northern Senegal (http://ohmi-tessekere.in2p3.fr/projets; http://projetcerise-ird-frb.fr), we had the opportunity to sample different rodent communities within human settlements from several villages (indoor sites) and natural wild habitats (outdoor sites) in the Ferlo region. This area represents a colonization front for two invasive rodent species: (i) The house mouse (Mus musculus), a major invasive species worldwide [2] that was introduced to Senegal in the colonial period, and which tends to replace native rodent communities (mainly Mastomys erythroleucus and Arvicanthis niloticus) with various consequences in disease risk and ecological interactions within invaded communities [20-22]; (ii) the Nigerian gerbil (Gerbillus nigeriae) that recently colonized North Senegal thanks to climatic and environmental changes experienced by the Sahelian bioclimatic zone during the last three decades, where it now represents the dominant species in outdoor rodent assemblages [23].

Here, we conducted an epidemiological investigation of the bacterial communities of different native and invasive rodent populations from North Senegal (Ferlo region). We aimed to (i) characterize the presence and phylogenetic position of potentially zoonotic pathogens (including unknown or unsuspected species), (ii) identify their distribution within host rodent populations relationships with environmental (indoor vs. outdoor sites) and host (species, invasive vs. native), and (iii) discuss the potential impact they may have in regard of public health issues.

\section{Results}

\subsection{Specimens Included in the Study}

Among the small mammals caught (complete data not published), 171 spleen samples were considered in the current work, all belonging to rodents of the family Muridae: i) 50 rodents from outdoor trapping sites, including 15 Arvicanthis niloticus, 20 Gerbillus nigeriae, and 15 Taterillus sp. (most probably corresponding to T. pygargus), these species represented by far the three dominant ones of northern Senegal outdoors rodent communities [24]; ii) 121 rodents from indoor trapping sites, including 26 A. niloticus (11 from Diagali and 15 from Fourdou), 44 Mastomys erythroleucus (12 from Diagali, 10 from Fourdou, 1 from Labgar, and 21 from Ranerou) and 51 Mus musculus (17 from Labgar, 16 from Tessekere, and 18 from Yonofere).

\subsection{Molecular Screening}

All methodological details, such as the type of PCR used, the portion of sequence considered, and the spectrum of species targeted, are provided in Table 1. Below, we focused only on bacteria detected and identified in each host species. 
Table 1. Oligonucleotide sequences of primers and probe used for qPCRs and conventional PCRs in this study.

\begin{tabular}{|c|c|c|c|c|c|c|}
\hline Targets & Targeted Gene & Name & Primers $\left(5^{\prime}-3^{\prime}\right)$ and Probes (Used for qPCR Screening or Sequencing) & Annealing Temperature & Specificity & References \\
\hline \multirow[b]{2}{*}{ Piroplasmida } & $5.8 \mathrm{~S}$ & $\begin{array}{l}5.8 \mathrm{~S}-\mathrm{F} 5 \\
5.8 S-\mathrm{R} \\
5.8 \mathrm{~S}-\mathrm{S}\end{array}$ & $\begin{array}{c}\text { AYYKTYAGCGRTGGATGTC } \\
\text { TCGCAGRAGTCTKCAAGTC } \\
\text { FAM-TTYGCTGCGTCCTTCATCGTTGT-MGB }\end{array}$ & $60^{\circ} \mathrm{C}$ & Broad-range qPCR & [25] \\
\hline & $\begin{array}{c}18 \mathrm{~S} \\
(969-\mathrm{bp})\end{array}$ & $\begin{array}{l}\text { piro18S-F1 } \\
\text { piro18S-F4 } \\
\text { piro18S-F3 } \\
\text { piro18S-R3 } \\
\end{array}$ & $\begin{array}{c}\text { GCGAATGGCTCATTAIAACA } \\
\text { CACATCTAAGGAAGGCAGCA } \\
\text { GTAGGGTATTGGCCTACCG** } \\
\text { AGGACTACGACGGTATCTGA* } \\
\end{array}$ & $58^{\circ} \mathrm{C}$ & Broad-range conventional PCR & [25] \\
\hline \multirow[t]{2}{*}{ Anaplasma } & $23 \mathrm{~S}$ & $\begin{array}{l}\text { TtAna_F } \\
\text { TtAna_R } \\
\text { TtAna_P }\end{array}$ & $\begin{array}{c}\text { TGACAGCGTACCTTTTGCAT } \\
\text { GTAACAGGTTCGGTCCTCCA } \\
\text { 6FAM-GGATTAGACCCGAAACCAAG } \\
\end{array}$ & $55^{\circ} \mathrm{C}$ & Broad-range $\mathrm{qPCR}$ & [26] \\
\hline & $23 \mathrm{~S}$ (520-bp) & $\begin{array}{l}\text { Ana23S-212F } \\
\text { Ana23S-753R }\end{array}$ & $\begin{array}{l}\text { ATAAGCTGCGGGGAATTGTC } \\
\text { TGCAAAAGGTACGCTGTCAC }\end{array}$ & $58^{\circ} \mathrm{C}$ & Broad-range conventional PCR & [26] \\
\hline \multirow{3}{*}{ Borrelia } & $23 \mathrm{~S}$ & $\begin{array}{c}\text { TTB23s } \\
\text { FTTB23s } \\
\text { RTTB23s P } \\
\end{array}$ & $\begin{array}{c}\text { CGATACCAGGGAAGTGAAC } \\
\text { ACAACCCYMTAAATGCAACG } \\
\text { 6FAM-TTTGATTTCTTTTCCTCAGGG-TAMRA } \\
\end{array}$ & $60^{\circ} \mathrm{C}$ & Broad-range $\mathrm{qPCR}$ & [27] \\
\hline & $g l p Q$ & $\begin{array}{l}\text { Bcroci_glpQ_F } \\
\text { Bcroci_glpQ_R } \\
\text { Bcroci_glpQ_P }\end{array}$ & $\begin{array}{c}\text { CCTTGGATACCCCAAATCATC } \\
\text { GGCAATGCATCAATTCTAAAC } \\
\text { 6FAM- ATGGACAAATGACAGGTCTTAC -MGB }\end{array}$ & $60^{\circ} \mathrm{C}$ & Species-specific qPCR & [27] \\
\hline & Fla (640-bp) & $\begin{array}{l}\text { Fla120F } \\
\text { Fla800R }\end{array}$ & $\begin{array}{l}\text { TGATGATGCTGCTGGWATGG } \\
\text { TTGGAAAGCACCIARATTTGC }\end{array}$ & $58^{\circ} \mathrm{C}$ & Broad-range conventional PCR & This study \\
\hline \multirow[t]{2}{*}{ Bartonella } & ITS & $\begin{array}{l}\text { Barto_ITS3_F } \\
\text { Barto_ITS3_R } \\
\text { Barto_ITS3_P }\end{array}$ & $\begin{array}{c}\text { GATGCCGGGGAAGGTTTTC } \\
\text { GCCTGGGAGGACTTGAACCT } \\
\text { 6FAM-GCGCGCGCTTGATAAGCGTG }\end{array}$ & $60^{\circ} \mathrm{C}$ & Broad-range $\mathrm{qPCR}$ & [28] \\
\hline & ITS (733-bp) & $\begin{array}{l}\text { Urbarto1 } \\
\text { Urbarto2 }\end{array}$ & $\begin{array}{l}\text { CTTCGTTTCTCTTTCTTCA } \\
\text { CTTCTCTTCACAATTCAAT }\end{array}$ & $50^{\circ} \mathrm{C}$ & Broad-range conventional PCR & [29] \\
\hline $\begin{array}{l}\text { Streptobacillus } \\
\text { monilliformis }\end{array}$ & gyrB & $\begin{array}{l}\text { Smoni-gyrB-F } \\
\text { Smoni-gyrB-R } \\
\text { Smoni-gyrB-P }\end{array}$ & $\begin{array}{c}\text { AGTTTAAAATTCCCTGAACCACAATT } \\
\text { ACTTCCAAACACTCCTGAAACTATACTTG } \\
\text { 6FAM-TCACAAACTAAGGCAAAACTTGGTTCATCTGAG }\end{array}$ & $60^{\circ} \mathrm{C}$ & Species-specific qPCR & [30] \\
\hline Occidentia & sca & $\begin{array}{l}\text { OMscaA-F } \\
\text { OMscaA-R } \\
\text { OMscaA-P }\end{array}$ & $\begin{array}{c}\text { AAGGCCAAAAGCATTAGCAA } \\
\text { TTCATTTGTATGAATTCCTTGCAT } \\
\text { TGAAGTTGAAGATGTCCCTAATAGT }\end{array}$ & $55^{\circ} \mathrm{C}$ & Species-specific qPCR & This study \\
\hline \multirow[t]{2}{*}{$\begin{array}{l}\text { Coxiella } \\
\text { Burnetii }\end{array}$} & IS1111A & $\begin{array}{l}\text { CB_IS1111_0706F } \\
\text { CB_IS11110706R } \\
\text { CB_IS1111_0706P }\end{array}$ & $\begin{array}{c}\text { CAAGAAACGTATCGCTGTGGC } \\
\text { CACAGAGCCACCGATGAATC } \\
\text { 6FAM-CCGAGTTCGAAACAATGAGGGCTG }\end{array}$ & $60^{\circ} \mathrm{C}$ & Species-specific qPCR & [28] \\
\hline & IS $30 \mathrm{~A}$ & $\begin{array}{l}\text { CB_IS30A_3F } \\
\text { CB_IS30_3R } \\
\text { CB_IS30A_3P }\end{array}$ & $\begin{array}{c}\text { CGCTGACCTACAGAAATATGTCC } \\
\text { GGGGTAAGTAAATAATACCTTCTGG } \\
\text { 6FAM-CATGAAGCGATTTATCAATACGTGTATGC }\end{array}$ & $60^{\circ} \mathrm{C}$ & Species-specific qPCR & [28] \\
\hline
\end{tabular}


Table 1. Cont.

\begin{tabular}{|c|c|c|c|c|c|c|}
\hline Targets & Targeted Gene & Name & Primers $\left(5^{\prime}-3^{\prime}\right)$ and Probes (Used for qPCR Screening or Sequencing) & Annealing Temperature & Specificity & References \\
\hline Rickettsia & $g l t A(C S)$ & $\begin{array}{l}\text { RKND03_F } \\
\text { RKND03_R } \\
\text { RKND03 P }\end{array}$ & $\begin{array}{c}\text { GTGAATGAAAGATTACACTATTTAT } \\
\text { GTATCTTAGCAATCATTCTAATAGC } \\
\text { 6FAM-CTATTATGCTTGCGGCTGTCGGTTC }\end{array}$ & $60^{\circ} \mathrm{C}$ & Broad-range qPCR & [28] \\
\hline Hepatozoon & $18 \mathrm{~S}(620-\mathrm{bp})$ & $\begin{array}{l}\text { H14Hepa18SFw } \\
\text { H14Hepa18SRv }\end{array}$ & $\begin{array}{l}\text { GAAATAACAATACAAGGCAGTTAAAATGCT } \\
\text { GTGCTGAAGGAGTCGTTATAAAGA }\end{array}$ & $58^{\circ} \mathrm{C}$ & Broad-range conventional PCR & [31] \\
\hline Mycoplasma & & $\begin{array}{l}\text { Mycop_ITS_F } \\
\text { Mycop_ITS_R } \\
\text { Mycop_ITS_P }\end{array}$ & $\begin{array}{c}\text { GGGAGCTGGTAATACCCAAAGT } \\
\text { CCATCCCCACGTTCTCGTAG } \\
\text { 6FAM-GCCTAAGGTAGGACTGGTGACTGGGG }\end{array}$ & $60^{\circ} \mathrm{C}$ & Broad-range qPCR & [32] \\
\hline Plasmodium & ssrRNA (231-bp) & $\begin{array}{l}\text { rPLU1 } \\
\text { rPLU2 } \\
\text { rPLU3 } \\
\text { rPLU4 }\end{array}$ & $\begin{array}{c}\text { TCAAAGATTAAGCCATGCAAGTGA } \\
\text { ATCTAAGAATTTCACCTCTGACATCTG } \\
\text { TTTTTATAAGGATAACTACGGAAAAACTGT } \\
\text { TACCCGTCATAGCCA-TGTTAGGCCAATACC }\end{array}$ & $62{ }^{\circ} \mathrm{C}$ & Broad-range nested PCR & [33] \\
\hline Pan-Filarioidea & $28 \mathrm{~S}$ & $\begin{array}{l}\text { qFil-28S-F } \\
\text { qFil-28S-R } \\
\text { qFil-28S-P }\end{array}$ & $\begin{array}{c}\text { TTGTTTGAGATTGCAGCCCA } \\
\text { GTTTCCATCTCAGCGGTTTC } \\
\text { 6FAM-ACTTTCCCTCACGGTACTTG } \\
\end{array}$ & $60^{\circ} \mathrm{C}$ & Broad-range qPCR & $\begin{array}{l}\text { Laidoudi et al., } \\
\text { in press }\end{array}$ \\
\hline \multirow[t]{2}{*}{ Pan-Kinetoplastida } & $28 S L S U$ & $\begin{array}{l}\text { P LSU 24a } \\
\text { F LSU 24a } \\
\text { R LSU 24a }\end{array}$ & $\begin{array}{c}\text { 6FAM-TAGGAAGACCGATAGCGAACAAGTAG } \\
\text { AGTATTGAGCCAAAGAAGG } \\
\text { TTGTCACGACTTCAGGTTCTAT }\end{array}$ & $60^{\circ} \mathrm{C}$ & Broad-range $\mathrm{qPCR}$ & \multirow[t]{2}{*}{ [34] } \\
\hline & & $\begin{array}{l}\text { F2 28S } \\
\text { R1 28S }\end{array}$ & $\begin{array}{l}\text { ACCAAGGAGTCAAACAGACG } \\
\text { GACGCCACATATCCCTAAG }\end{array}$ & $53^{\circ} \mathrm{C}$ & Broad-range conventional PCR & \\
\hline
\end{tabular}


The presence of the DNA of Piroplasmida spp. was screened, and four spleens were positive (4/171, $2.3 \%$ ) (one from Taterillus sp., one from A. niloticus, and two from M. musculus). We succeeded in amplifying and sequencing only one sample (of $A$. niloticus). The phylogenetic analysis showed that this protozoan occupies an intermediate position between the genera Theileria and Babesia (Figure 1). Its GenBank accession number is MK484070.

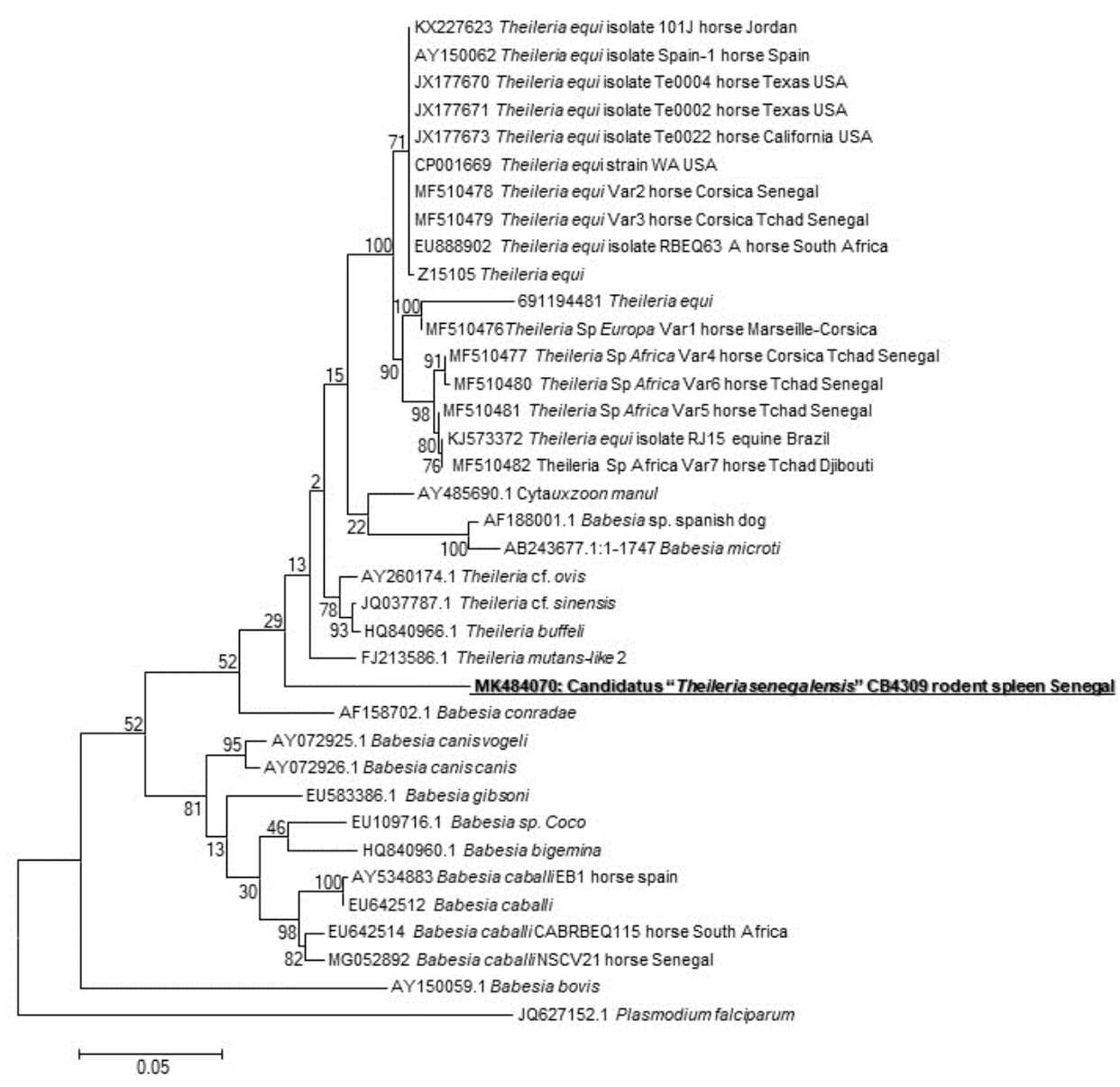

Figure 1. Maximum-likelihood phylogenetic tree of piroplasms, based on partial 880-bp 18S gene, including potentially new species identified in this study.

In Bartonella spp. screening, 16/171 (9.35\%) of samples were positive (nine from Taterillus sp., four from $A$. niloticus, and three from $M$. erythroleucus). We could successfully amplify 10 positive samples (seven from Taterillus sp., two from A. niloticus, and one from M. erythroleucus). The comparison of the sequences obtained showed that there were three different genotypes. When blasted, the first genotype (GenBank accession number: MK558846) corresponded to B. pachyuromydis AB602561, the closest validated species with only $92 \%$ of homology. The second (GenBank accession number: MK559409) showed 97\% with B. mastomydis KY555067. The third (GenBank accession number: MK559410) was found to be very different, and the closest species is B. tribocorum JF766268 having a query cover of $47 \%$ and $85 \%$ of homology (Figure 2 ). 


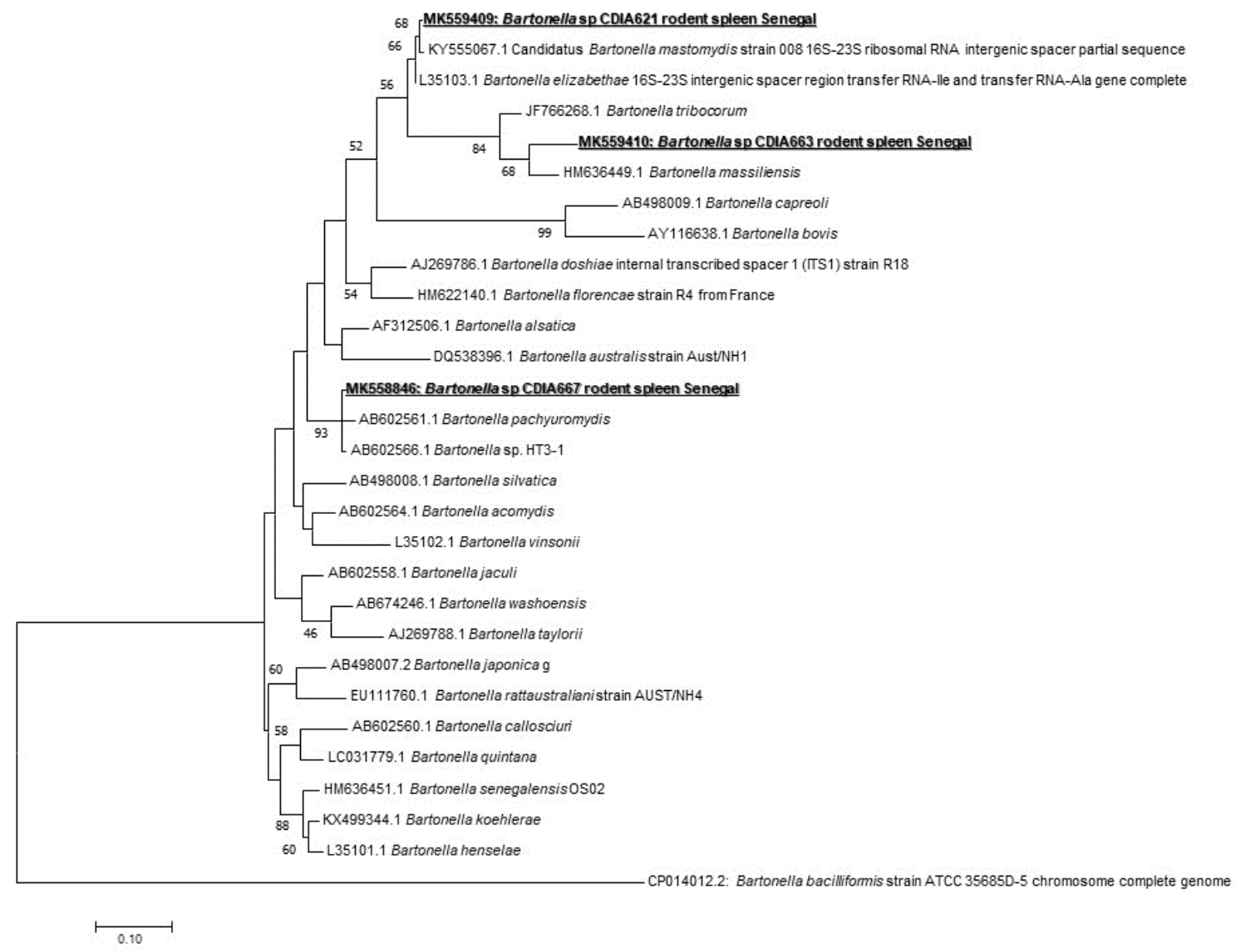

Figure 2. Maximum-likelihood phylogenetic tree of Bartonella spp, including new genotypes identified in this study based on partial 733-bp ITS gene.

We found 31 (18.12\%) samples positive for Anaplasmataceae species, i.e., 7 M. musculus, 1 G. nigeriae, 1 Taterillus sp., 17 A. niloticus, and $5 \mathrm{M}$. erythroleucus. To identify the species infecting rodents, we used a broad species PCR tool targeting the $23 \mathrm{~S}$ gene. Only five positive samples have been successfully amplified and sequenced (one from M. erythroleucus, four from A. niloticus). The comparison of the sequences obtained showed that they were all identical, which may mean that all these sequences belong to the same Anaplasmataceae species. When compared with other Anaplasmataceae species, the 520 bps-long amplicons of $23 S$ rRNA gene obtained from Senegalese rodents did not match to any officially recognized species. Based on its position on the phylogenetic tree (Figure 3), it may be attributed to a potentially new species of Ehrlichia. This is clearly reflected by its position on the phylogenetic tree based on the $23 \mathrm{~S}$ gene and by only $95 \%$ of identity with the closest species, Ehrlichia ruminantium NR077002 (Figure 3). The obtained GenBank accession numbers for its different genotypes are MK484067, MK484068, and MK484069.

When screening for the Hepatozoon spp. harbored by rodents, we found $4 / 171(2.33 \%)$ positive spleen samples. The sequencing of a 620-bps-long portion revealed three species of Hepatozoon sp. Two samples corresponded to Hepatozoon sp. closely related to those isolated from snakes in the north of Africa [35]: KC696569 found in M. erythroleucus and KC696565 that we found in A. niloticus. Two other sequences belong to two different genotypes of Hepatozoon canis, both of them found in M. musculus (Figure 4). 

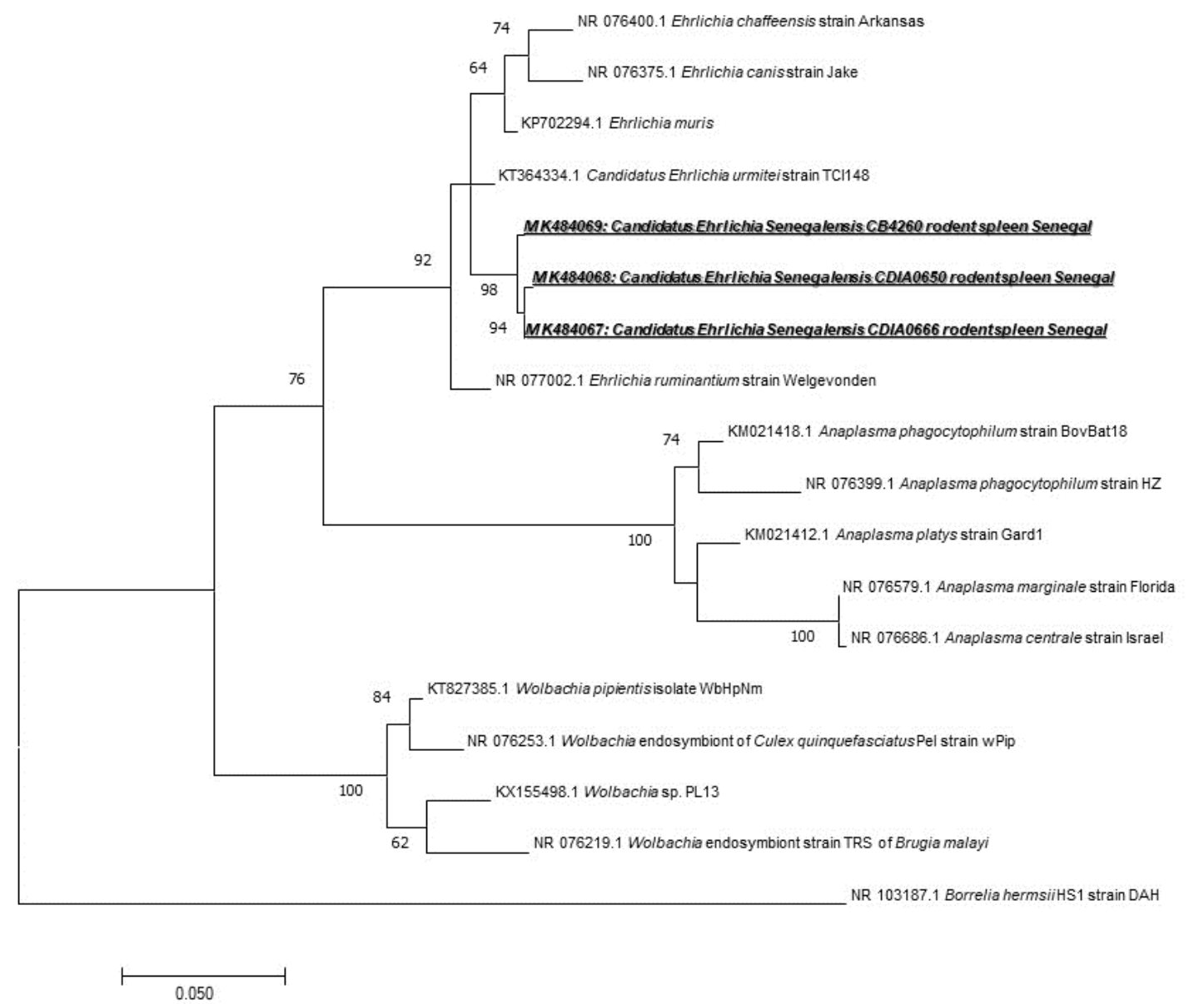

Figure 3. Maximum-likelihood phylogenetic tree of Anaplasmataceae spp, including new genotypes from this study based on the partial 520-bp 235 gene.

We also found 6/171 (3.5\%); one from M. musculus, one from G. nigeriae, one from Taterillus sp., and three from M. erythroleucus) to be positive for Filarioidea. In their amplification and sequencing, we failed to get a representative sequence clearly identifying the species infecting the rodents we screened.

To detect Leishmania spp. and Trypanosoma spp., the spleen samples were screened for the presence of Kinetoplastidae DNA. We found 6/171 positive (3.5\%; one from G. nigeriae, four from Taterillus sp., and one from M. erythroleucus). While, in their amplification, we failed to obtain the amplicons to sequence to identify the species.

We also screened our samples for the presence of Borrelia spp. DNA. We found 26/171 (15.2\%) spleen samples to be positive (five M. musculus, two G. nigeriae, five Taterillus sp., seven from A. niloticus, and seven from $M$. erythroleucus). To identify the species, we first screened the positive samples for the presence of B. crocidurae DNA, and we found only 8/26 (30.76\%) to be positive, so 8/171 (4.67\%) on the total of spleen samples. We designed a standard PCR fla gene to amplify different representatives of Borrelia spp. And all eight samples previously found positive for B. crocidurae by qPCR were successfully amplified. The sequenced $640 \mathrm{bps}$-long amplicons of the flagellin gene were identical to B. crocidurae (JX292914) for all eight (Figure 5) (one from G. nigeriae, two from M. erythroleucus, four from A. niloticus, and one from Taterillus sp). It is interesting to note that five were found in rodents captured indoors, while three were found in rodents captured outdoors.

We screened our samples for Orientia and O. massiliensis DNA, the new genus of the Rickettsiaceae family. The new specific qPCR tool is very sensitive to our positive controls and does not detect DNA from other bacteria or organisms, but no spleen sample was found positive. Similarly, no positive results were detected for some of the pathogens we tested with the systems we used. It is the case for Coxiella burnetii, Plasmodium spp., Rickettsia spp., Mycoplasma spp., and Streptobacillus moniliformis. 


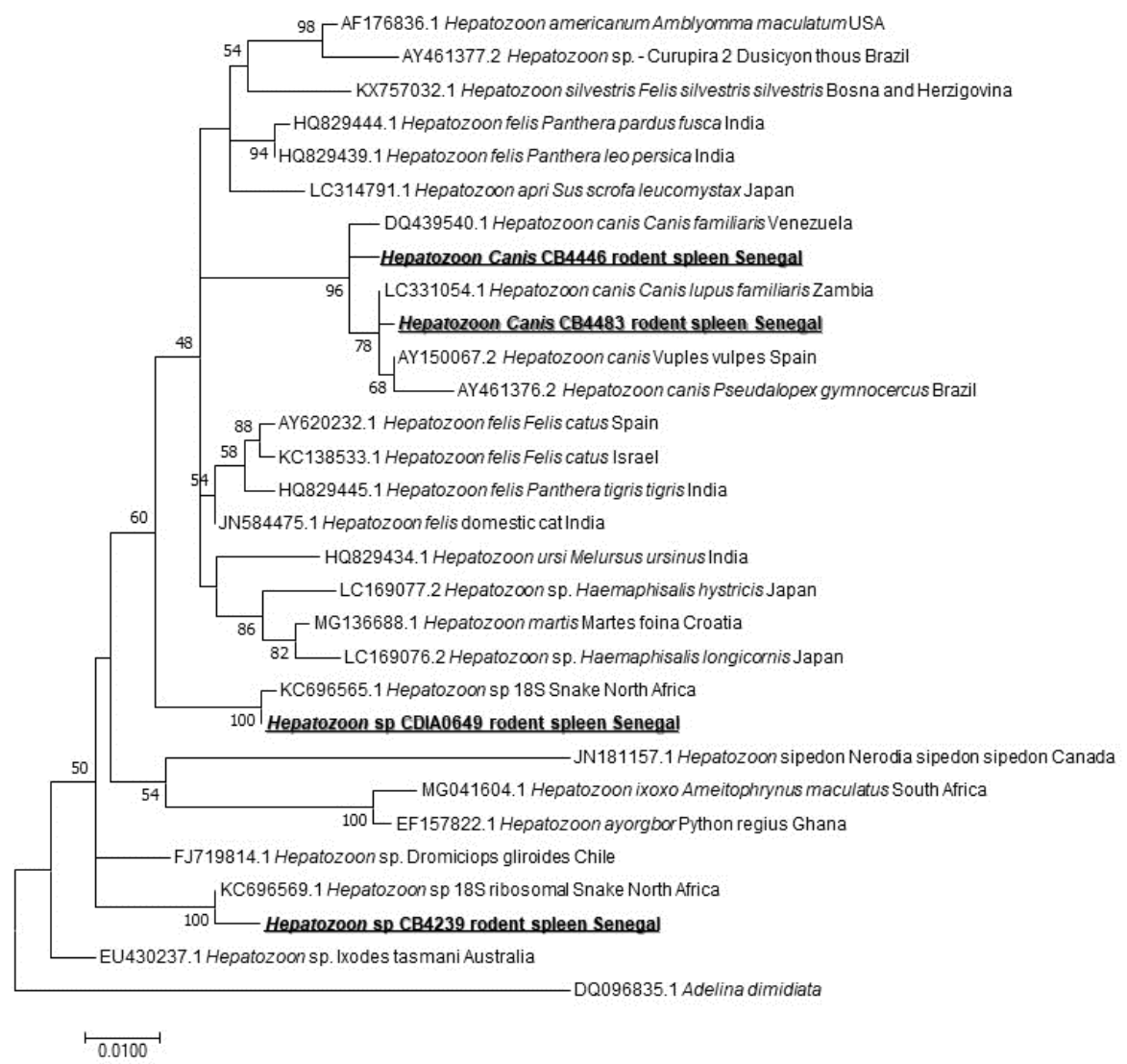

Figure 4. Maximum-likelihood phylogenetic tree of Hepatozoon spp, including new genotypes from this study based on partial 620-bp $18 \mathrm{~S}$ gene.

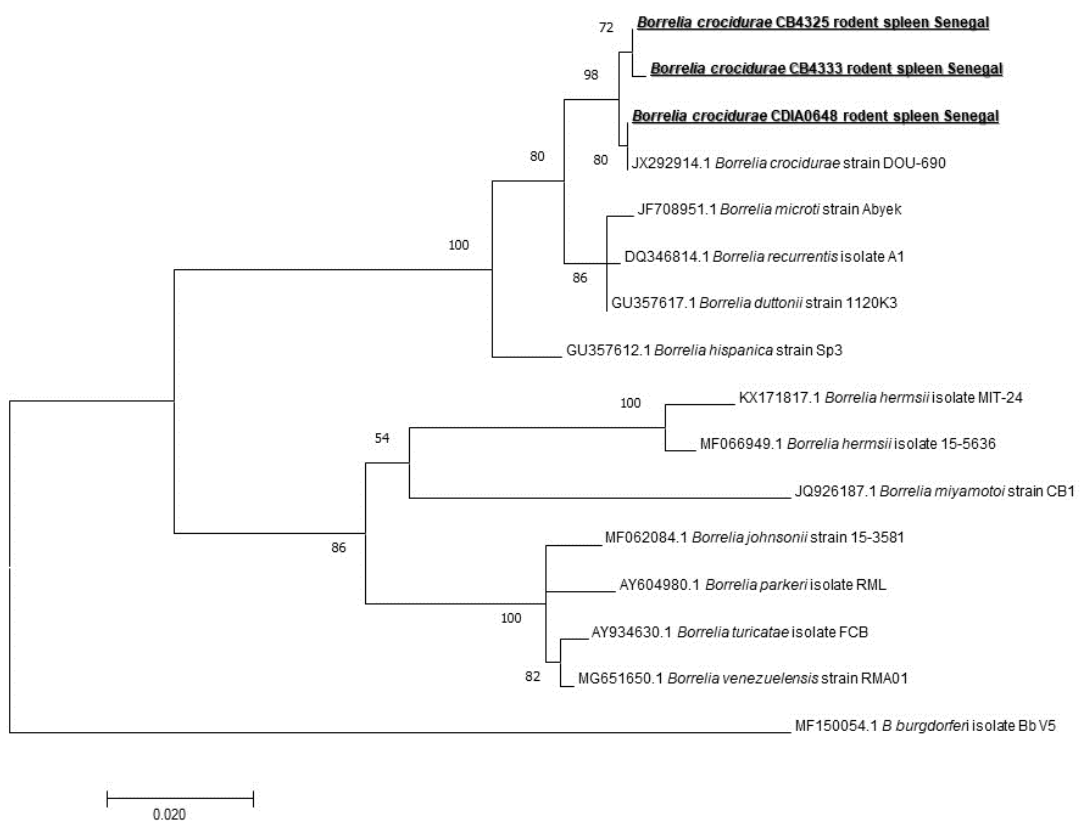

Figure 5. Maximum-likelihood phylogenetic tree of Borrelia spp, including new genotypes based on the partial 640-bp flagellin gene $(f l a B)$.

\subsection{Host-pathogens Relationships}

More details regarding the genotypes of pathogens we identified and their related species are provided in Table 2. 
Table 2. Different genotypes of pathogens identified in this study and their related rodent species.

\begin{tabular}{|c|c|c|c|c|c|c|c|c|c|c|c|c|c|c|}
\hline \multirow[b]{3}{*}{ Pathogen } & \multirow{3}{*}{$\begin{array}{l}\mathrm{qPCR} \\
\text { Positive } \\
\text { Samples }\end{array}$} & \multirow{3}{*}{$\begin{array}{l}\text { Amplified } \\
\text { Genotypes }\end{array}$} & \multirow{3}{*}{$\begin{array}{l}\text { About the Amplified } \\
\text { Genotypes }\end{array}$} & \multirow[b]{3}{*}{ Total } & \multicolumn{6}{|c|}{ Native } & \multicolumn{4}{|c|}{ Invasive } \\
\hline & & & & & \multicolumn{2}{|c|}{ Aroicanthis niloticus } & \multicolumn{2}{|c|}{ Mastomys erythroleucus } & \multicolumn{2}{|c|}{ Taterillus sp. } & \multicolumn{2}{|c|}{ Mus musculus } & \multicolumn{2}{|c|}{ Gerbillus nigeriae } \\
\hline & & & & & $\begin{array}{l}\text { Indoor } \\
(\mathrm{N}=26)\end{array}$ & $\begin{array}{l}\text { Outdoor } \\
(\mathrm{N}=15)\end{array}$ & $\begin{array}{l}\text { Indoor } \\
(\mathrm{N}=44)\end{array}$ & $\begin{array}{l}\text { Outdoor } \\
(\mathrm{N}=0)\end{array}$ & $\begin{array}{l}\text { Indoor } \\
(\mathrm{N}=0)\end{array}$ & $\begin{array}{l}\text { Outdoor } \\
(\mathrm{N}=15)\end{array}$ & $\begin{array}{l}\text { Indoor } \\
(\mathrm{N}=51)\end{array}$ & $\begin{array}{l}\text { Outdoor } \\
(N=0)\end{array}$ & $\begin{array}{l}\text { Indoor } \\
(N=0)\end{array}$ & $\begin{array}{l}\text { Outdoor } \\
(N=20)\end{array}$ \\
\hline Piroplasma & $4 / 171(2.3 \%)$ & $\begin{array}{l}\text { Piroplasmida sp. } \\
\text { "Arvicantis } \\
\text { CB4309" }\end{array}$ & Potential new species & 1 & $1 / 26(3.8 \%)$ & 0 & 0 & 0 & 0 & 0 & 0 & 0 & 0 & 0 \\
\hline \multirow{3}{*}{ Bartonella } & \multirow{3}{*}{$16 / 171(9.35 \%)$} & Genotype 1 & $\begin{array}{l}\text { Potential new genotype: } \\
92 \% \text { of homology with } \\
\text { B. pachyuromydis AB602561 }\end{array}$ & 4 & 0 & 0 & $1(2.3 \%)$ & 0 & 0 & $3 / 15(20 \%)$ & 0 & 0 & 0 & 0 \\
\hline & & Genotype 2 & $\begin{array}{l}\text { Potential new genotype: } \\
97 \% \text { of homology with B. } \\
\text { mastomydis KY555067 }\end{array}$ & 1 & 0 & 0 & 0 & 0 & 0 & $1 / 15(6.7 \%)$ & 0 & 0 & 0 & 0 \\
\hline & & Genotype 3 & $\begin{array}{l}\text { Potential new genotype: } \\
85 \% \text { of homology with } \\
\text { B. tribocorum (JF766268) }\end{array}$ & 5 & $1 / 26(3.8 \%)$ & $1 / 15(6.7 \%)$ & 0 & 0 & 0 & $3 / 15(20 \%)$ & 0 & 0 & 0 & 0 \\
\hline Borrelia & 26/171 (15.2\%) & Borrelia crocidurae & $\begin{array}{l}\text { Identical to B. crocidurae } \\
\text { JX292914 }\end{array}$ & 8 & $3 / 26(11.5 \%)$ & $1 / 15(6.7 \%)$ & $2(4.5 \%)$ & 0 & 0 & $1 / 15(6.7 \%)$ & 0 & 0 & 0 & $1 / 20(5 \%)$ \\
\hline Anaplasma & $31(18.12 \%)$ & $\begin{array}{l}\text { Candidatus } \\
\text { "Ehrlichia } \\
\text { senegalensis" }\end{array}$ & Potential new species & 5 & $1 / 26(3.8 \%)$ & $3 / 15(20 \%)$ & $1(2.3 \%)$ & 0 & 0 & 0 & 0 & 0 & 0 & 0 \\
\hline \multirow{3}{*}{ Hepatozoon } & \multirow{3}{*}{$\begin{array}{c}4 / 171(2.33 \%) \\
\text { by } \\
\text { conventional } \\
\text { PCR tool }\end{array}$} & Hepatozoon sp. & $\begin{array}{c}\text { Closely related to } \\
\text { Hepatozoon sp. KC696569 }\end{array}$ & 1 & 0 & 0 & $1(2.3 \%)$ & 0 & 0 & 0 & 0 & 0 & 0 & 0 \\
\hline & & Hepatozoon sp. & $\begin{array}{c}\text { Closely related to } \\
\text { Hepatozeoon sp. KC696565 }\end{array}$ & 1 & 0 & $1 / 15(6.7 \%)$ & 0 & 0 & 0 & 0 & 0 & 0 & 0 & 0 \\
\hline & & Hepatozoon canis & Closely related to $H$. canis & 2 & 0 & 0 & 0 & 0 & 0 & 0 & $2 / 51(3.9 \%)$ & 0 & 0 & 0 \\
\hline
\end{tabular}


For overall prevalence, the best model selected revealed a significant effect of the gender $(\log$-likelihood ratio tests $(\mathrm{LRT})=4.5226, p=0.0335)$ and the species status $(\mathrm{LRT}=18.2631, p<0.0001)$. Male and invasive rodents appeared to be less infected than female and native ones, respectively. For specific prevalence, model selection was carried out only for Borrelia and Anaplasma as the prevalence of the other bacterial taxa did not exceed $10 \%$ in the entire dataset. We exclusively found a positive correlation between host body mass and infection by Anaplasma (LRT $=13.519$, $p=0.0002$ ). For individual richness, the most parsimonious model contained host gender and species status as explanatory variables. Nonetheless, only the species status had a significant effect (LRT $=10.6649, p=0.0011$ ) with native rodent individuals harboring a greater diversity of bacterial taxa than invasive ones.

\section{Discussion}

A rise in human diseases associated with small-mammals reservoirs was documented, and studies were conducted to assess better the link between vertebrate host ecology and human diseases [7]. Diseases of public health interest that can be transmitted by rodents are extensively studied $[4,15,20,36-39]$.

Here, an epidemiological investigation of potentially zoonotic bacteria and parasites from native and invasive rodent communities in Senegal was carried out principally using PCR tools designed to amplify a broad range of species. From the 13 pathogens we tested, 7 were detected using the broad range of qPCR tools, while 5 (Piroplasmida spp., Hepatozoon spp., Bartonella spp., Borrelia spp., and Anaplasmatacea spp.) were amplified and sequenced to be identified and to investigate their phylogeny. We also found that indoor rodents appeared generally less infected than outdoor ones and that invasive rodents were less infected than native ones.

We used widespread species and sensitive qPCR system targeting the 16S-23S rRNA internal transcribed spacer region ITS gene to be able to detect the largest range of Bartonella species. Sixteen individuals (9.35\%) (nine from Taterillus sp., four from A. niloticus, and three from M. erythroleucus) were positive. This global prevalence is particularly similar to those previously reported 9\%) [40]. Diagne et al. [19] previously reported Bartonella spp. in R. rattus, M. erythroleucus, M. natalensis, and M. musculus from Senegal without identifying the species. In Spain, a study showed a prevalence of $18.8 \%$ in rodents, while $13.6 \%$ of their ectoparasites were also infected, highlighting that humans are at risk of infection for Bartonella [41]. Only 10 samples were successfully amplified by standard PCR (seven from Taterillus sp., two from A. niloticus, and one from M. erythroleucus). The amplicons give three potentially new genotypes. Several studies showed different genotypes of the same species [40] or even new species [19]. The first new genotype with $92 \%$ of homology with B. pachyuromydis AB602561 (the closest validated species) was detected in four rodents, three Taterillus sp., and one M. erythroleucus). The second, only observed in Taterillus sp, exhibited 97\% homology with B. mastomydis KY555067. The third genotype is quite distant from all known Bartonella species, showing only $85 \%$ homology with B. tribocorum (JF766268). It was found in five rodents (two A. niloticus and three Taterillus sp.). New species isolated recently from rodents in the southern part of Senegal named Candidatus "B. raoultii" and "B. mastomydis" were recovered from M. erythroleucus, while Candidatus "B. saheliensis" was recovered from G. gambianus [19]. The number of Bartonella species is increasing and has doubled over the last 15 years [42]. More than 30 species are currently described, and, interestingly, more than half are harbored by rodents. With such numbers of new species with unknown pathogenicity, rodents may constitute potential effective reservoirs for Bartonella that threatens public health. Among those known to be potentially zoonotic, we can cite B. tribocorum, B. grahamii, B. elizabethae, B. vinsonii subsp. arupensis, B. washoensis, and B. alsatica [40]. In addition, in rodents' ectoparasites, a high prevalence of zoonotic bartonellosis agents were found (43.75\% of B. elizabethae in Stenoponia tripectinata tripectinata) [41]. The close contacts among humans and rodents seem to create excellent conditions for the transmission of Bartonella spp. [42]. Here, the contacts between A. niloticus, M. erythroleucus, and humans can be very 
frequent as these rodents are very anthropophilic and often commensal, although they are gradually being replaced by the house mouse M. musculus in Senegal [3].

Borrelia are spirochete bacteria infecting humans or animals and are transmitted to both of them by the bite of arthropods, such as ticks, mites, and lice. They are usually divided into two taxonomic groups: lyme disease group and relapsing fever group, both containing many human pathogens. An increasing number of emerging or novel borrelial species are reported [43]. Tick-borne relapsing fever (TBRF) is an acute febrile illness caused by several Borrelia species [44]. They are usually transmitted by bites of Ornithodoros soft ticks $[45,46]$. Endemic in Senegal, B. crocidurae is responsible for West African tick-borne relapsing fever (TBRF) and Ornithodoros sonrai. Living in rodents burrows is its vector [47]. Humans contract the disease when they are bitten by a tick living in rodent habitats. It may cause up to $5 \%$ of mortality if left untreated [7]. TBRF is a very important disease in Northern Senegal. The morbidity rates may be very high in rural areas and, overlapping malaria may be the most frequent cause of acute febrile disease consulted in rural dispensaries [48], so it is very important to understand its epidemiology. We detected 26/171 (15.2\%) positive samples by broad species qPCR system. Only 8 of these 26 samples were confirmed as B. crocidurae. Borrelia crocidurae was reported in Senegal [20], Mauritania, Algeria, Mali [47], Morocco, Libya, Egypt, Iran, and Turkey [7]. A longitudinal study conducted on the West African tick-borne relapsing fever reported that the average incidence of TBRF over 14 years was 11 per 100 person-years. The average $B$. crocidurae infection rate of its vector $O$. sonrai was $31 \%$ [49]. In our study, all eight sequences were identical to B. crocidurae JX292914 (one from G. nigeriae, two from M. erythroleucus, four from A. niloticus, and one from Taterillus sp.). Studies conducted in West African countries, especially Senegal, have shown that using direct thick blood film examinations that Meriones spp., Tatera gambiana, Taterillus gracilis (complex), Cricetomys gambianus, M. erythroleucus, Rattus rattus, A. niloticus, Mus musculus, Taterillus sp., and M. huberti and some insectivores, such as Crocidura sp., function as hosts for B. crocidurae [7,49-53]. New genotypes of this TBRF agent continue to be isolated and identified [44,54]. In our study, the presence of this neglected bacterium in M. musculus, M. erythroleucus, A. niloticus, and Taterillus sp. was confirmed using molecular tools. We report it for the first time in G. nigeriae, which is an invasive species in Senegal, which may have acquired the infection by exchange from native rodent species. It should be pointed out that there is a possibility that it was brought by the species probably from Mauritania.

Within the order of Rickettsiales, we found the Anaplasmataceae family, which is composed of Gram-negative Alphaproteobacteria, including genera Anaplasma, Ehrlichia, Neorickettsia, Neoehrlichia, Aegyptianella, and Wolbachia. They are known to cause infections in humans as well as in domestic and wild animals [55], and previous studies have reported a high prevalence of Anaplasmataceae in rodents [7] in Senegal [20]. Rodents are often the hosts for ticks and reservoirs of pathogens. Wood rats, white-footed mice, and squirrels, for instance, are hosts of Ixodes spp., and reservoirs of Anaplasma spp. ticks are easily infected on rodents, and then, when they bite humans, transmit the agent that causes human granulocyte anaplasmosis (HGA) in several regions of the world [7]. Previous studies reported the detection of Anaplasma phagocytophilum and A. ovis in sheep in Senegal [56]. We used a broad species qPCR tool to detect Anaplasmataceae [26]. We found 31/171 (18.12\%) positive spleens. In only five individuals, Anaplasmataceae bacteria were successfully amplified and sequenced (one from M. erythroleucus, four from $A$. niloticus). The analysis of the amplicons obtained suggests that it may represent a potentially new species of Ehrlichia. It is clearly visible by the position of this sequence on the phylogenetic tree based on the 235 gene and which has $95 \%$ homology with Ehrlichia ruminantium NR077002 (Figure 3). According to the current taxonomy rules [57], we propose the Candidatus status and the following provisional name Candidatus "Ehrlichia senegalensis", whose pathogenicity remains unknown. Recently, there has been an increase in the genetic diversity of Anaplasmataceae and newly described species worldwide [55,58-61]. Other species isolated from rodents, such as A. phagocytophilum and A. muris, may affect humans. It would be necessary to isolate it and to pursue studies on its epidemiology and microbiology. 
The Hepatozoon genus, apicomplexan blood parasites described in snakes and also in all tetrapod groups [35], is known to use a wide range of vertebrates as intermediate hosts, such as amphibians, reptiles, birds, as well as domestic and wild mammals. They commonly get the parasite by the ingestion of infected invertebrate hosts (diverse blood-sucking arthropods) [62]. They are also transmitted by arthropods, such as ticks [63], or arthropods are ingested by the definitive host (snakes versus mosquitoes) [64]. Non-vector transmission may also happen, such as vertical transmission demonstrated in dogs [65] The screening of the Hepatozoon spp. revealed 4/171 (2.33\%) positive (one M. erythroleucus, one A. niloticus, two M. musculus). Screening for the Hepatozoon spp. in rodents reported in the United States of America found a47\% positivity rate [63], and up to $67 \%$ in Finland, $17 \%$ in Spain, and up to $41.6 \%$ in Poland [66], which is much higher than our results. The sequencing of the amplicons revealed three genotypes of the Hepatozoon sp. Two of them were found in M. erythroleucus, and A. niloticus. Both are very close to the two Hepatozoon sp. identified in snakes in North Africa (KC696569 and KC696565). In snakes, the genus Hepatozoon is the (most identified) hemogregarine prey-predator transmitted agent and various studies reported a possible connection between the lineages found in predators and those found in the respective preys [35]. A study carried out in the Mediterranean region, showed two Hepatozoon types that have been previously reported in lacertids and gekkonids, identified from two genera of snakes known to have a diet including such lizards [35]: two ball pythons experimentally infected by Hepatozoon using laboratory mice livers that had been previously inoculated with Hepatozoon ayorgbor [64]. We can suggest that the rodents we studied harbored Hepatozoon species and act as intermediate hosts for snakes hepatozoonosis. The third genotype identified is represented by two slightly different sequences, both of them found in M. musculus. This genotype is very close to H. canis. Various studies support the idea that Hepatozoon americanum, the causative agent of canine hepatozoonosis, can be transmitted by predation, and Hepatozoon spp. have been widely reported from rodents in Europe, Africa, North and South America [62].

Kinetoplastidae are widely reported from rodents, especially Leishmania [67] and Trypanosoma [68]. Their ability to infect humans has been evaluated and proven for some species [68]. We also detected them in group-specific qPCR but were unable to amplify any specific gene. This may be explained by the lack of broad-range PCR tools for the amplification of potentially unknown Kinetoplastidae.

We found four qPCR-positive samples (4/171: 2.33\%) to piroplasmids. Only one (1/171: $0.58 \%$ ) was successfully amplified from an A. niloticus spleen sample. To the best of our knowledge, our study is the first to provide evidence of piroplasmids circulating in A. niloticus. We can find some studies screening the presence of piroplasmids (belonging to the genera Babesia, Theileria, Cytauxzoon, and Rangelia) in different rodent species $[11,69,70]$. These tick-borne apicomplexan protozoans cause typical zoonotic diseases by parasitizing blood cells of numerous wild and domestic vertebrates worldwide, resulting in major economic and veterinary impacts [69]. Hundreds of human babesiosis cases are attributed to rodent Babesia transmitted by Ixodes scapularis [71]. Analysis of the sequence of a portion of the $18 \mathrm{~S}$ rRNA gene obtained from A. niloticus revealed that it might represent a new species having $90 \%$ identity with several Theileria species. The phylogenetic tree based on the 880 bps-long portion of the $18 \mathrm{~S}$ gene showed that our sequence comprises both those of Babesia and Theileria species. Unable to attribute obtained sequence to one of the closest genera (Theileria or Babesia), we retain the provisional name Piroplasmida sp. "Arvicantis CB4309". While investigating the diversity of piroplasmids in wild rodents, a study conducted in Brazil on Thrichomys fosteri $(\mathrm{N}=77)$, Oecomys mamorae $(\mathrm{N}=25)$, and Clyomys laticeps $(\mathrm{N}=8)$ revealed that $6 / 77(7.8 \%)$ T. fosteri were infected. The sequencing of the $18 \mathrm{~S}$ rRNA gene showed 99\% identity with B. vogeli KT323934 for five of them, while the last one showed 99\% identity with T. equi KU672386 using BLAST analysis [69]. Another study investigating B. microti in rodents in Croatia reported a prevalence of 6\% (2/36 individuals) in Myodes glareolus, and 16.2\% (6/37) in Apodemus flavicollis, highlighting the need for more serious consideration of Babesia infection in humans [72]. New species or new genotypes of piroplasmids are sometimes found in rodents samples [71,73], and their pathogenicity remains unknown. It may present a risk for public health, so it is necessary that they be given more attention. 
The PCR tools we have used for our screening are specific to the genus or family of microorganisms, which may allow us to detect new potential pathogens. Subsequently, almost all the pathogens we found in our study are new genotypes or new species. However, some positives detected in qPCR were not amplified. This may be due to the fact that the conventional tools are not degenerated enough to amplify them to the high sensitivity of the qPCR tools compared to the conventional ones.

As previously shown in commensal rodents from Senegal [20], our data revealed that gender and body mass, as well as the native/invasive status of the rodents, may significantly drive the bacterial infection in rodents. These preliminary results must be interpreted with caution regarding the distribution of our data (e.g., only a single species was captured in both indoor and outdoor habitats) and call for more refined and specific analyses. Nevertheless, our findings provided interesting and surprising preliminary patterns. First, we found that individuals with higher body mass were more susceptible to infection by Anaplasma. The reasons potentially explaining why larger rodents may be more prone to higher infection levels than lighter ones were already discussed elsewhere [20], although other specific mechanisms can be involved. Second, we found that females were overall more infected than males, which was not consistent with neither the common trend of higher parasitism rates in males [74,75] nor previous findings on bacterial communities of commensal rodents in Senegal [20]. Indeed, this result rather corroborated the hypothesis according to which sex bias in pathogen infection natural small mammal populations may depend on a variety of interacting parasite-related, host-related, and environmental factors that can vary in both space and time within natural (small mammal) populations, even within the same host-parasite association [76,77]. Indeed, sexual differences in physiology, behavior, and evolutionary roles, have been shown to impact both the susceptibility and the exposition to different pathogens [74]. For instance, Gryzbek et al. [78] evidenced that mature and reproductively active female bank voles are subject to higher exposure to helminths. Furthermore, the interplay between resistance and tolerance, the two main immune strategies implemented by a host when it is challenged by a parasite $[79,80]$, was shown to differ substantially between male and female rodents [81]. Gender-biased infections remain, therefore, a challenging area in ecological research. Third, our results were in line with the expectation of lower parasitism highly documented in invading populations during their geographical spread (enemy release hypothesis; [82-84]); details and potential mechanisms are presented and discussed elsewhere (e.g., [21,85-87]). Our findings were consistent with previous ones obtained for the house mouse in Senegal (e.g., [21]), and might provide the first empirical evidence for either low infection rates and/or potential parasite reduction experienced by the Nigerian gerbil during its geographical spread in West Africa. However, to conclude on this point requires a robust biogeographical comparison between well-defined source and currently invading populations of this rodent species. Nonetheless, our work brought novel evidence for lower infection levels in invasive vs. native rodents, which may translate into a competitive advantage for both resources and space due to higher fitness and body condition [82]. Finally, this would contribute to explaining why both exotic rodents currently experience a successful ongoing spread in Senegal.

Molecular epidemiology remains a powerful and effective tool in wildlife health investigations, including surveillance and research, which is used to face the rapid increase in the number of animal and human-wildlife diseases [88].

Overall, this article presents the results of screening different rodent species in Senegal for multiple zoonotic agents. We confirmed that rodents constitute a powerful source of zoonotic pathogens that are still poorly studied, especially in Africa. The presence of rodents in human dwellings can present a significant risk of contracting infectious diseases. In the present case, domestic and peri-domestic rodents in Senegal were confirmed to be the host of an important human pathogen, B. crocidurae, constituting a reservoir for this endemic infection. The roles of other bacteria and protozoa identified in the present study in human and animal pathology are yet to be identified. 


\section{Materials and Methods}

\subsection{Ethics Statement}

Fieldwork was carried out under the framework agreements established between the French National Research Institute for Development (IRD) and the Republic of Senegal, as well as with the Senegalese Water and Forest Management Head Office of the Ministry of Environment and Sustainable Development. None of the rodent species investigated in the present study has protected status (see UICN and CITES lists). Handling procedures were performed under the CBGP agreement for experiments on wild animals (no. D-34-169-1) and followed the official guidelines of the American Society of Mammalogists [89]. Trapping campaigns were systematically performed with prior explicit agreement from relevant local authorities, and from the owners of the buildings/houses where domestic trapping was performed.

\subsection{Study Area and Samples Collection}

The following localities and their immediate surroundings were sampled: (i) four localities along the national road $\mathrm{n}^{\circ} 3$ crossing the Ferlo eastwards, visited in February-March 2017: Diagali (15.27 $7^{\circ}$, $\left.14.67^{\circ} \mathrm{W}\right)$, Yonofere $\left(15.27^{\circ} \mathrm{N}, 14.46^{\circ} \mathrm{W}\right)$, Fourdou $\left(15.22^{\circ} \mathrm{N}, 14.16^{\circ} \mathrm{W}\right)$, and Ranerou $\left(15.30^{\circ} \mathrm{N}\right.$, $\left.13.96^{\circ} \mathrm{W}\right)$, (ii) two localities within the Great Green Wall area in northwestern Ferlo, visited in May 2017: Labgar $\left(15.83^{\circ} \mathrm{N}, 14.81^{\circ} \mathrm{W}\right)$ and Tessekere $\left(15.86^{\circ} \mathrm{N}, 15.06^{\circ} \mathrm{W}\right)$ (Figure 6). We used both locally made single capture wire-mesh live traps $(8.5 \times 8.5 \times 26.5 \mathrm{~cm})$ and Sherman folding box traps $(8 \times 9 \times$ $23 \mathrm{~cm}$ ), baited once a day with peanut butter pasted on fresh onion slices. Indoor traps were set inside buildings (dwelling houses, storehouses, or shops) for trapping sessions of one to three consecutive days. A variable number of rooms were sampled in each site and trapping session, with typically two traps (one wire-mesh and one Sherman) set per room. Outdoor traps were installed for 1-3 days in lines with an inter-trap interval of $10 \mathrm{~m}$ or were grouped in a priori favorable microhabitats (as suggested by the conspicuous presence of active burrows). Traps were checked every morning for night captures, and every afternoon (while re-baiting) for daily captures.

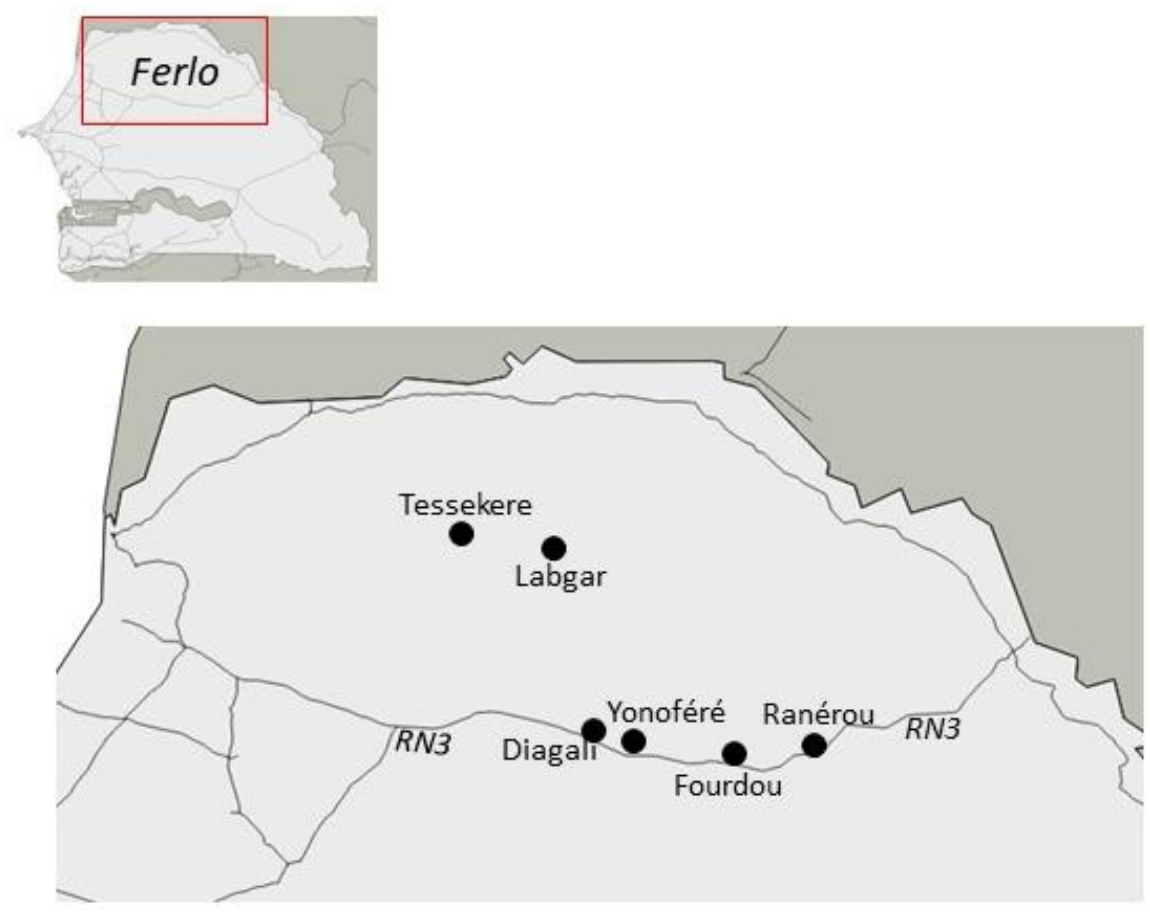

Figure 6. Map of localities where samples were collected in Ferlo (North Senegal). 
The small mammals specimens that were caught were identified according to morphological, and, when necessary, molecular (using cytochrome $b$ gene sequence) criteria, as previously reported [17]. Upon autopsy, classical body measurements were taken, reproductive status was noted, and organ samples (including spleen used in the present study) were preserved in ethanol $95 \%$ for further analyses. Small mammals were captured and handled in accordance with relevant requirements of Senegalese legislation and live animal capture and handling guidelines described at http://ilmbwww.gov.bc.ca/ risc/pubs/tebiodiv/capt/assets/capt.pdf.

\subsection{DNA Extraction}

For each spleen, a small piece was crushed and incubated overnight with lysis buffer and proteinase $\mathrm{K}$, before DNA extraction performed using EZ1 DNA kits (Qiagen, Courtaboeuf, France), according to the manufacturer's protocol. The DNA extracts were then stored at $-20^{\circ} \mathrm{C}$ until PCR analysis.

\subsection{Pathogens DNA Detection, PCR Amplification, and Phylogenetic Analysis}

Thirteen groups of pathogens, most of them zoonotic, have been screened: Piroplasma spp., Coxiella burnetii, Bartonella spp., Plasmodium spp., Hepatozoon spp., Borrelia spp., Anaplasmataceae, Rickettsia spp., Mycoplasma spp., Orientia spp., and Occidentia massiliensis, Streptobacillus moniliformis, Filarioidea spp., Kinetoplastida spp.).

The initial screening of samples was performed using qPCR systems with wide specificity (genusor family-specific) (Table 1). For real-time qPCR, the reaction mix contained $5 \mu \mathrm{L}$ of the DNA template, $10 \mu \mathrm{L}$ of EurogentecTakyon ${ }^{\mathrm{TM}} \mathrm{Mix}$ (Eurogentec, Liège, Belgium), $0.5 \mu \mathrm{L}(20 \mu \mathrm{M})$ of each reverse and forward primers, $0.5 \mu \mathrm{L}(5 \mu \mathrm{M})$ of the FAM-labeled probe) and $3.5 \mu \mathrm{L}$ of distilled water DNAse and RNAse free, for a final volume of $20 \mu \mathrm{L}$. The real-time qPCR amplification was carried out in a CFX96 Real-Time system (Bio-Rad Laboratories, Foster City, CA, USA) using the following thermal profile: incubation at $50^{\circ} \mathrm{C}$ for two minutes for UDG action (eliminating PCR amplicons' contaminant), then an activation step at $95^{\circ} \mathrm{C}$ for three minutes followed by 40 cycles of denaturation at $95^{\circ} \mathrm{C}$ for 15 seconds and an annealing-extension at $60^{\circ} \mathrm{C}$ for 30 seconds.

The identification of qPCR positive samples is based on the amplification and then sequencing using wide-range genus or family-specific systems. We designed new tools for this study, and we confirmed their sensitivity and specificity before using them (Supplementary Materials Table S1). PCR reactions contained $5 \mu \mathrm{L}$ of the DNA template, $25 \mu \mathrm{L}$ of Amplitaq-Gold STAR ${ }^{\text {TM }}$ Mix (Eurogentec), $10 \mu \mathrm{M}(1 \mu \mathrm{L})$ of each primer and $18 \mu \mathrm{L}$ of distilled water DNAse and RNAse free. The amplifications were performed in a Peltier PTC-200 model thermal cycler (MJ Research Inc., Watertown, MA, USA).

The conditions for conventional PCR were as follows: one incubation step at $95{ }^{\circ} \mathrm{C}$ for 15 minutes, 40 cycles of one minute at $95{ }^{\circ} \mathrm{C}, 30$ seconds annealing at a different hybridization temperature for each PCR assay, and one minute at $72{ }^{\circ} \mathrm{C}$, followed by a final extension for five minutes at $72{ }^{\circ} \mathrm{C}$ (Table 1). Negative and positive controls were included in each molecular assay. The success of amplification was confirmed by electrophoresis on a $1.5 \%$ agarose gel. The purification of PCR products was performed using NucleoFast 96 PCR plates (Macherey-Nagel, Hoerdt, France) according to the manufacturer's instructions.

The amplicons were sequenced using the Big Dye Terminator Cycle Sequencing Kit (Perkin Elmer Applied Biosystems, Foster City, CA, USA) with an ABI automated sequencer (Applied Biosystems). The obtained sequences were assembled and edited using ChromasPro software (ChromasPro 1.7, Technelysium Pty Ltd., Tewantin, Australia). Then, the sequences were compared with those available in the GenBank database by NCBI BLAST (http://blast.ncbi.nlm.nih.gov/Blast.cgi). Phylogenetic analyses and tree construction were performed using MEGA software version 7.0.21 [90] with 100 bootstrap replications. 


\subsection{Statistical Analysis}

Generalized linear mixed models (GLMMs) were used to evaluate whether host factors (species, gender, body mass), the status (native vs. invasive), and/or the type of habitat (indoor vs. outdoor) influence the infection level of the rodents. We considered individual bacterial richness (number of bacterial taxa recorded in a single individual host) and both specific (infection by a bacterial taxon for which prevalence reached at least $10 \%$ in the global dataset) and overall (infection by any bacterial taxon, combining all taxa) prevalence as response variables. We assumed a binomial distribution for prevalence data and a Poisson distribution for richness data, respectively. The sampling site was considered as a random factor. A model selection approach was performed, using the Akaike information criterion with correction for samples of finite size (AICc). The starting models included all the factors as possible predictors. The most parsimonious model among those selected within two AIC units of the best model was chosen. The significance of explanatory variables and their interactions was determined by deletion testing and log-likelihood ratio tests (LRT). The assumptions of each final model were ensured by checking the model dispersion and normality, independence and variance homogeneity of the residuals. All analyses were performed using the packages MuMIn v1.15.1 [26] and lme4 v1.1-8 [27] implemented in R software v3.2.1 [28].

Supplementary Materials: The following are available online at http://www.mdpi.com/2076-0817/9/3/202/s1. Table S1. The list of negative and positive DNA controls used to confirm the sensitivity and specificity of the PCR systems designed for this study.

Author Contributions: H.D.: Methodology; investigation; software; writing—original draft preparation; L.G.: Conceptualization; investigation; methodology; validation; writing - review and editing; C.D.: Conceptualization; methodology; software; validation; writing - review and editing; B.D.: Conceptualization; methodology; writing - review and editing. F.F.: Methodology; validation; writing —review and editing; supervision. O.M.: Conceptualization; methodology; validation; writing—review and editing; supervision. All authors have read and agreed to the published version of the manuscript.

Funding: This study was supported by the Institut Hospitalo-Universitaire (IHU) Méditerranée Infection, the National Research Agency under the program «Investissements d'avenir », reference ANR-10-IAHU-03. This work was co-funded by the Labex DRIIHM, French programme "Investissements d'Avenir" (ANR-11-LABX-0010), which is managed by the ANR.

Conflicts of Interest: The authors declare no conflict of interest. The funders had no role in study design, data collection, and analysis, decision to publish, or preparation of the manuscript.

\section{References}

1. Capizzi, D.; Bertolino, S.; Mortelliti, A. Rating the rat: Global patterns and research priorities in impacts and management of rodent pests. Mamm. Rev. 2014, 44, 148-162. [CrossRef]

2. Dalecky, A.; Bâ, K.; Piry, S.; Lippens, C.; Diagne, C.A.; Kane, M.; Sow, A.; Diallo, M.; Niang, Y.; Konečný, A.; et al. Range expansion of the invasive house mouse Mus musculus domesticus in Senegal, West Africa: A synthesis of trapping data over three decades, 1983-2014. Mamm. Rev. 2015, 45, 176-190. [CrossRef]

3. Hassell, J.M.; Begon, M.; Ward, M.J.; Fèvre, E.M. Urbanization and Disease Emergence: Dynamics at the Wildlife-Livestock-Human Interface. Trends Ecol. Evol. 2017, 32, 55-67. [CrossRef]

4. Taylor, P.J.; Arntzen, L.; Hayter, M.; Iles, M.; Frean, J.; Belmain, S. Understanding and managing sanitary risks due to rodent zoonoses in an African city: Beyond the Boston Model. Integr. Zool. 2008, 3, 38-50. [CrossRef] [PubMed]

5. Dobigny, G.; Garba, M.; Tatard, C.; Loiseau, A.; Galan, M.; Kadaouré, I.; Rossi, J.-P.; Picardeau, M.; Bertherat, E. Urban Market Gardening and Rodent-Borne Pathogenic Leptospira in Arid Zones: A Case Study in Niamey, Niger. PLoS Negl. Trop. Dis. 2015, 9, e0004097. [CrossRef] [PubMed]

6. Buckle, A.P.; Smith, R. Rodent Pests and Their Control; CABI: Wallingford, UK, 2014.

7. Meerburg, B.G.; Singleton, G.R.; Kijlstra, A. Rodent-borne diseases and their risks for public health Rodent-borne diseases and their risks for public health. Crit. Rev. Microbiol. 2009, 35, 221-270. [CrossRef] [PubMed]

8. Shimi, A.; Keyhani, M.; Hedayati, K. Studies on salmonellosis in the house mouse. Mus Musculus. Lab. Anim. 1979, 13, 33-34. [CrossRef] 
9. Reperant, L.A.; Deplazes, P. Cluster of Capillaria hepatica infections in non-commensal rodents from the canton of Geneva, Switzerland. Parasitol. Res. 2005, 96, 340-342. [CrossRef]

10. Riehm, J.M.; Tserennorov, D.; Kiefer, D.; Stuermer, I.W.; Tomaso, H.; Zoller, L.; Otgonbaatar, D.; Scholz, H.C. Yersinia pestis in small rodents, Mongolia. Emerg. Infect. Dis. 2011, 17, 1320-1322. [CrossRef]

11. Obiegala, A.; Pfeffer, M.; Pfister, K.; Karnath, C.; Silaghi, C. Molecular examinations of Babesia microti in rodents and rodent-attached ticks from urban and sylvatic habitats in Germany. Ticks Tick. Borne. Dis. 2015, 6, 445-449. [CrossRef]

12. Goeijenbier, M.; Wagenaar, J.; Goris, M.; Martina, B.; Henttonen, H.; Vaheri, A.; Reusken, C.; Hartskeerl, R.; Osterhaus, A.; Van Gorp, E. Rodent-borne hemorrhagic fevers: Under-recognized, widely spread and preventable-epidemiology, diagnostics and treatment. Crit. Rev. Microbiol. 2013, 39, 26-42. [CrossRef] [PubMed]

13. van Soolingen, D.; van der Zanden, A.G.; de Haas, P.E.; Noordhoek, G.T.; Kiers, A.; Foudraine, N.A.; Portaels, F.; Kolk, A.H.; Kremer, K.; van Embden, J.D. Diagnosis of Mycobacterium microti infections among humans by using novel genetic markers. J. Clin. Microbiol. 1998, 36, 1840-1845. [CrossRef]

14. Kim, C.-M.; Yi, Y.-H.; Yu, D.-H.; Lee, M.-J.; Cho, M.-R.; Desai, A.R.; Shringi, S.; Klein, T.A.; Kim, H.-C.; Song, J.-W.; et al. Tick-Borne Rickettsial Pathogens in Ticks and Small Mammals in Korea. Appl. Environ. Microbiol. 2006, 72, 5766-5776. [CrossRef] [PubMed]

15. Rabiee, M.H.; Mahmoudi, A.; Siahsarvie, R.; Kryštufek, B.; Mostafavi, E. Rodent-borne diseases and their public health importance in Iran. PLoS Negl. Trop. Dis. 2018, 12, e0006256. [CrossRef] [PubMed]

16. Duplantier, J.M.; Granjon, L.; Adam, F.B.K. Répartition Actuelle du rat noir (Rattus rattus) au Sénégal: Facteurs Historiques et Ecologiques. In Actes du colloque "Le Rongeur et l'Espace $n^{\circ} 2$ »; Le Berre, M., Le Guelte, L., Eds.; Chabaud éditions: Lyon, France, 1991; pp. 339-346.

17. Granjon, L.; Duplantier, J.M. Les Rongeurs de l'Afrique Sahelo-Soudanienne; Editions de l'IRD: Marseille, France, 2009.

18. Duplantier, J.M.; Granjon, L.; Bâ, K. Répartition biogéo-graphique des petits rongeurs au Sénégal. J. Afr. Zool. 1997, 111, 17-26.

19. Mediannikov, O.; Aubadie, M.; Bassene, H.; Diatta, G.; Granjon, L.; Fenollar, F. Three new Bartonella species from rodents in Senegal. Int. J. Infect. Dis. 2014, 21, 335. [CrossRef]

20. Diagne, C.; Galan, M.; Tamisier, L.; D’Ambrosio, J.; Dalecky, A.; Bâ, K.; Kane, M.; Niang, Y.; Diallo, M.; Sow, A.; et al. Ecological and sanitary impacts of bacterial communities associated to biological invasions in African commensal rodent communities. Sci. Rep. 2017, 7, 1-11. [CrossRef]

21. Diagne, C.; Ribas, A.; Charbonnel, N.; Dalecky, A.; Tatard, C.; Gauthier, P.; Haukisalmi, V.; Fossati-Gaschignard, O.; Bâ, K.; Kane, M.; et al. Parasites and invasions: Changes in gastrointestinal helminth assemblages in invasive and native rodents in Senegal. Int. J. Parasitol. 2016, 46, 857-869. [CrossRef]

22. Diagne, C.; Gilot-Fromont, E.; Cornet, S.; Husse, L.; Doucouré, S.; Dalecky, A.; Bâ, K.; Kane, M.; Niang, Y.; Diallo, M. Contemporary variations of immune responsiveness during range expansion of two invasive rodents in Senegal. Oikos 2017, 126, 435-446. [CrossRef]

23. Thiam, M.; Bâ, K.; Duplantier, J.-M. Impacts of climatic changes on small mammal communities in the Sahel (West Africa) as evidenced by owl pellet analysis. Afr. Zool. 2008, 43, 135-143. [CrossRef]

24. Boëtsch, G.; Guissé, A.; Duboz, P. La Grande Muraille Verte-CNRS Editions. Available online: http: //www.cnrseditions.fr/sociologie-ethnologie-anthropologie/7835-la-grande-muraille-verte.html (accessed on 3 April 2019).

25. Dahmana, H.; Amanzougaghene, N.; Davoust, B.; Normand, T.; Carette, O.; Demoncheaux, J.-P.; Mulot, B.; Fabrizy, B.; Scandola, P.; Chik, M.; et al. Great diversity of Piroplasmida in Equidae in Africa and Europe, including potential new species. Vet. Parasitol. Reg. Stud. Rep. 2019, 18, 100332. [CrossRef] [PubMed]

26. Dahmani, M.; Davoust, B.; Tahir, D.; Raoult, D.; Fenollar, F.; Mediannikov, O. Molecular investigation and phylogeny of Anaplasmataceae species infecting domestic animals and ticks in Corsica, France. Parasit. Vectors 2017, 10, 302. [CrossRef]

27. Subramanian, G.; Sekeyova, Z.; Raoult, D.; Mediannikov, O. Multiple tick-associated bacteria in Ixodes ricinus from Slovakia. Ticks Tick. Borne. Dis. 2012, 3, 406-410. [CrossRef] [PubMed]

28. Sokhna, C.; Mediannikov, O.; Fenollar, F.; Bassene, H.; Diatta, G.; Tall, A.; Trape, J.-F.; Drancourt, M.; Raoult, D. Point-of-care laboratory of pathogen diagnosis in rural Senegal. PLoS Negl. Trop. Dis. 2013, 7, e1999. [CrossRef] [PubMed] 
29. Jensen, W.A.; Fall, M.Z.; Rooney, J.; Kordick, D.L.; Breitschwerdt, E.B. Rapid identification and differentiation of Bartonella species using a single-step PCR assay. J. Clin. Microbiol. 2000, 38, 1717-1722. [CrossRef] [PubMed]

30. Musser, K.A.; Passaretti, T.; Mitchell, K.K.; Huth, P.; Smith, G.; Davidson, A.; Dickinson, M.; Kidney, A.; Cole, J.; Dumas, N.; et al. Detection of Streptobacillus moniliformis in whole blood by real-time PCR and review of clinical cases 2004-2015 in New York State. J. Microbiol. Infect. Dis. 2017, 7, 88-92.

31. Hodžić, A.; Alić, A.; Prašović, S.; Otranto, D.; Baneth, G.; Duscher, G.G. Hepatozoon silvestris sp. nov.: Morphological and molecular characterization of a new species of Hepatozoon (Adeleorina: Hepatozoidae) from the European wild cat (Felis silvestris silvestris). Parasitology 2017, 144, 650-661. [CrossRef]

32. Bittar, F.; Keita, M.B.; Lagier, J.C.; Peeters, M.; Delaporte, E.; Raoult, D. Gorilla gorilla gorilla gut: A potential reservoir of pathogenic bacteria as revealed using culturomics and molecular tools. Sci. Rep. 2014, 4, 1-5. [CrossRef]

33. Obeid, M.; Franetich, J.-F.; Lorthiois, A.; Gego, A.; Grüner, A.C.; Tefit, M.; Boucheix, C.; Snounou, G.; Mazier, D. Skin-draining lymph node priming is sufficient to induce sterile immunity against pre-erythrocytic malaria. EMBO Mol. Med. 2013, 5, 250-263. [CrossRef]

34. Medkour, H.; Varloud, M.; Davoust, B.; Mediannikov, O. New Molecular Approach for the Detection of Kinetoplastida Parasites of Medical and Veterinary Interest. Microorganisms 2020, 8, 356. [CrossRef]

35. Tomé, B.; Maia, J.P.M.C.; Harris, D.J. Molecular Assessment of Apicomplexan Parasites in the Snake Psammophis from North Africa: Do Multiple Parasite Lineages Reflect the Final Vertebrate Host Diet? J. Parasitol. 2013, 99, 883-887. [CrossRef] [PubMed]

36. Piasecki, T.; Chrzastek, K.; Kasprzykowska, U. Mycoplasma pulmonis of Rodents as a Possible Human Pathogen. Vector Borne Zoonotic Dis. 2017, 17, 475-477. [CrossRef] [PubMed]

37. Tatard, C.; Garba, M.; Gauthier, P.; Hima, K.; Artige, E.; Dossou, D.K.H.J.; Gagaré, S.; Genson, G.; Truc, P.; Dobigny, G. Rodent-borne Trypanosoma from cities and villages of Niger and Nigeria: A special role for the invasive genus Rattus? Acta Trop. 2017, 171, 151-158. [CrossRef]

38. Cosson, J.F.; Galan, M.; Bard, E.; Razzauti, M.; Bernard, M.; Morand, S.; Brouat, C.; Dalecky, A.; Bâ, K.; Charbonnel, N.; et al. Detection of Orientia sp. DNA in rodents from Asia, West Africa and Europe. Parasit. Vectors 2015, 8, 172. [CrossRef] [PubMed]

39. Serge, M.; Frédéric, B.; Hsuan-Wien, C.; Julien, C.; Jean-François, C.; Maxime, G.; Gábor, Á.C.; Alex, G.D.; Alice, L.; Johan, M.; et al. Global parasite and Rattus rodent invasions: The consequences for rodent-borne diseases. Integr. Zool. 2015, 10, 409-423.

40. Kraljik, J.; Paziewska-Harris, A.; Miklisová, D.; Blaňarová, L.; Mošanský, L.; Bona, M.; Stanko, M. Genetic diversity of Bartonella genotypes found in the striped field mouse (Apodemus agrarius) in Central Europe. Parasitology 2016, 143, 1437-1442. [CrossRef]

41. Abreu-yanes, E.; Martin-alonso, A.; Martin-carrillo, N.; Livia, K.G.; Marrero-gagliardi, A.; Valladares, B.; Feliu, C.; Foronda, P. Bartonella in Rodents and Ectoparasites in the Canary Islands. Spain: New Insights into Host-Vector-Pathogen Relationships. Microb. Ecol. 2018, 75, 264-273. [CrossRef]

42. Martin-Alonso, A.; Houemenou, G.; Abreu-Yanes, E.; Valladares, B.; Feliu, C.; Foronda, P. Bartonella spp. in Small Mammals, Benin. Vector Borne Zoonotic Dis. 2016, 16, 229-237. [CrossRef]

43. Cutler, S.J.; Ruzic-Sabljic, E.; Potkonjak, A. Emerging borreliae-Expanding beyond Lyme borreliosis. Mol. Cell. Probes 2017, 31, 22-27. [CrossRef]

44. Diatta, G.; Duplantier, J.-M.; Granjon, L.; Bâ, K.; Chauvancy, G.; Ndiaye, M.; Trape, J.-F. Borrelia infection in small mammals in West Africa and its relationship with tick occurrence inside burrows. Acta Trop. 2015, 152, 131-140. [CrossRef]

45. Goutier, S.; Ferquel, E.; Pinel, C.; Bosseray, A.; Hoen, B.; Couetdic, G.; Bourahoui, A.; Lapostolle, C.; Pelloux, H.; Garnier, M.; et al. Borrelia crocidurae Meningo-encephalitis, West Africa. Emerg. Infect. Dis. 2013, 19, 301. [CrossRef] [PubMed]

46. Souidi, Y.; Boudebouch, N.; Ezikouri, S.; Belghyti, D.; Trape, J.-F.; Sarih, M. Borrelia crocidurae in Ornithodoros ticks from northwestern Morocco: A range extension in relation to climatic change? J. Vector Ecol. 2014, 39, 316-320. [CrossRef] [PubMed] 
47. Trape, J.-F.; Diatta, G.; Arnathau, C.; Bitam, I.; Sarih, M.; Belghyti, D.; Bouattour, A.; Elguero, E.; Vial, L.; Mané, Y.; et al. The epidemiology and geographic distribution of relapsing fever borreliosis in West and North Africa, with a review of the Ornithodoros erraticus complex (Acari: Ixodida). PLoS ONE 2013, 8, e78473. [CrossRef] [PubMed]

48. Mediannikov, O.; Socolovschi, C.; Bassene, H.; Diatta, G.; Ratmanov, P.; Fenollar, F.; Sokhna, C.; Raoult, D. Borrelia crocidurae infection in acutely febrile patients, Senegal. Emerg. Infect. Dis. 2014, 20, 1335-1338. [CrossRef]

49. Vial, L.; Diatta, G.; Tall, A.; Hadj Ba, E.; Bouganali, H.; Durand, P.; Sokhna, C.; Rogier, C.; Renaud, F.; Trape, J.F. Incidence of tick-borne relapsing fever in west Africa: Longitudinal study. Lancet 2006, 368, 37-43. [CrossRef]

50. Dobigny, G. Inventaire et Biogéographie des Rongeurs du Niger: Nuisance aux Cultures, Implications Dans Certains Problemes de Santé Publique et Vetérinaire, Rapport de Coopération (CSN Niger 1999-2000). <hal-00394489>2000. 2000. Available online: https://www.documentation.ird.fr/hor/fdi:010049962(accessed on 6 March 2020).

51. Godeluck, B.; Duplantier, J.-M.; Ba, K.; Trape, J.-F. A Longitudinal survey of Borrelia crocidurae prevalence in rodents and insectivores in Senegal. Am. J. Trop. Med. Hyg. 1994, 50, 165-168. [CrossRef]

52. Trape, J.F.; Godeluck, B.; Diatta, G.; Rogier, C.; Legros, F.; Albergel, J.; Pepin, Y.; Duplantier, J.M. The spread of tick-borne borreliosis in West Africa and its relationship to sub-Saharan drought. Am. J. Trop. Med. Hyg. 1996, 54, 289-293. [CrossRef]

53. Trape, J.F.; Duplantier, J.M.; Bouganali, H.; Godeluck, B.; Legros, F.; Cornet, J.P.; Camicas, J.L. Tick-borne borreliosis in West Africa. Lancet 1991, 337, 473-475. [CrossRef]

54. Fotso Fotso, A.; Mediannikov, O.; Padmanabhan, R.; Robert, C.; Fournier, P.-E.; Raoult, D.; Drancourt, M. Genome Sequence of Borrelia crocidurae Strain 03-02, a Clinical Isolate from Senegal. Genome Announc. 2014, 2. [CrossRef]

55. Benevenute, J.L.; Dumler, J.S.; Ogrzewalska, M.; Roque, A.L.R.; Mello, V.V.C.; de Sousa, K.C.M.; Gonçalves, L.R.; D'Andrea, P.S.; de Sampaio Lemos, E.R.; Machado, R.Z.; et al. Assessment of a quantitative $5^{\prime}$ nuclease real-time polymerase chain reaction using groEL gene for Ehrlichia and Anaplasma species in rodents in Brazil. Ticks Tick. Borne. Dis. 2017, 8, 646-656. [CrossRef]

56. Djiba, M.L.; Mediannikov, O.; Mbengue, M.; Thiongane, Y.; Molez, J.-F.; Seck, M.T.; Fenollar, F.; Raoult, D.; Ndiaye, M. Survey of Anaplasmataceae bacteria in sheep from Senegal. Trop. Anim. Health Prod. 2013, 45, 1557-1561. [CrossRef] [PubMed]

57. Murray RG, E.; Stackebrandt, E. Taxonomic Note: Implementation of the Provisional Status Candidatus for Incompletely Described Procaryotes. Int. J. Syst. Evol. Microbiol. 1995, 45, 186-187. [CrossRef] [PubMed]

58. Jahfari, S.; Claudia Coipan, E.; Fonville, M.; Docters van Leeuwen, A.; Hengeveld, P.; Heylen, D.; Heyman, P.; van Maanen, C.; Butler, C.M.; Földvári, G.; et al. Circulation of four Anaplasma phagocytophilum ecotypes in Europe. Parasites Vectors 2014, 7, 365. [CrossRef] [PubMed]

59. Pritt, B.S.; Sloan, L.M.; Hoang Johnson, D.K.; Munderloh, U.G.; Paskewitz, S.M.; McElroy, K.M.; McFadden, J.D.; Binnicker, M.J.; Neitzel, D.F.; Liu, G.; et al. Emergence of a New Pathogenic Ehrlichia Species, Wisconsin and Minnesota, 2009. N. Engl. J. Med. 2011, 365, 422-429. [CrossRef] [PubMed]

60. Matsumoto, K.; Takeuchi, T.; Yokoyama, N.; Katagiri, Y.; Ooshiro, M.; Zakimi, S.; Kawamori, F.; Ohashi, N.; Inokuma, H. Detection of the New Ehrlichia Species Closely Related to Ehrlichia ewingii from Haemaphysalis longicornis in Yonaguni Island, Okinawa, Japan. J. Vet. Med Sci. 2011, 73, 1485-1488. [CrossRef]

61. Vinasco, J.; Li, O.; Alvarado, A.; Diaz, D.; Hoyos, L.; Tabachi, L.; Sirigireddy, K.; Ferguson, C.; Moro, M.H. Molecular Evidence of a New Strain of Ehrlichia canis from South America. J. Clin. Microbiol. 2007, 45, 2716-2719. [CrossRef]

62. de Demoner, L.C.; Magro, N.M.; da Silva, M.R.L.; de Paula Antunes, J.M.A.; Calabuig, C.I.P.; O’Dwyer, L.H. Hepatozoon spp. infections in wild rodents in an area of endemic canine hepatozoonosis in southeastern Brazil. Ticks Tick. Borne. Dis. 2016, 7, 859-864. [CrossRef]

63. Johnson, E.M.; Allen, K.E.; Panciera, R.J.; Ewing, S.A.; Little, S.E.; Reichard, M.V. Field survey of rodents for Hepatozoon infections in an endemic focus of American canine hepatozoonosis. Vet. Parasitol. 2007, 150, 27-32. [CrossRef]

64. Sloboda, M.; Kamler, M.; Bulantová, J.; Votýpka, J.; Modrý, D. Rodents as intermediate hosts of Hepatozoon ayorgbor (Apicomplexa: Adeleina: Hepatozoidae) from the African ball python, Python regius? Fol. Paras. 2008, 55, 13-16. [CrossRef] 
65. Murata, T.; Inoue, M.; Tateyama, S.; Taura, Y. Vertical transmission of Hepatozoon canis in dogs; Japan. J. Vet. Med. Sci. 1993, 55, 867-868. [CrossRef]

66. Kamani, J.; Harrus, S.; Nachum-Biala, Y.; Gutiérrez, R.; Mumcuoglu, K.Y.; Baneth, G. Prevalence of Hepatozoon and Sarcocystis spp. in rodents and their ectoparasites in Nigeria. Acta Trop. 2018, 187, 124-128. [CrossRef] [PubMed]

67. Navea-Pérez, H.M.; Díaz-Sáez, V.; Corpas-López, V.; Merino-Espinosa, G.; Morillas-Márquez, F.; Martín-Sánchez, J. Leishmania infantum in wild rodents: Reservoirs or just irrelevant incidental hosts? Parasitol. Res. 2015, 114, 2363-2370. [CrossRef] [PubMed]

68. Pumhom, P.; Morand, S.; Tran, A.; Jittapalapong, S.; Desquesnes, M. Trypanosoma from rodents as potential source of infection in human-shaped landscapes of South-East Asia. Vet. Parasitol. 2015, 208, 174-180. [CrossRef] [PubMed]

69. de Sousa, K.C.M.; Fernandes, M.P.; Herrera, H.M.; Freschi, C.R.; Machado, R.Z.; André, M.R. Diversity of piroplasmids among wild and domestic mammals and ectoparasites in Pantanal wetland, Brazil. Ticks Tick. Borne. Dis. 2017, 9, 245-253. [CrossRef]

70. Saito-Ito, A.; Yano, Y.; Dantrakool, A.; Hashimoto, T.; Takada, N. Survey of Rodents and Ticks in Human Babesiosis Emergence Area in Japan: First Detection of Babesia microti-Like Parasites in Ixodes ovatus. J. Clin. Microbiol. 2004, 42, 2268-2270. [CrossRef]

71. Dantrakool, A.; Somboon, P.; Hashimoto, T.; Saito-Ito, A. Identification of a New Type of Babesia Species in Wild Rats (Bandicota indica) in Chiang Mai Province, Thailand. J. Clin. Microbiol. 2004, 42, 850-854. [CrossRef]

72. Beck, R.; Vojta, L.; Ćurković, S.; Mrljak, V.; Margaletić, J.; Habrun, B. Molecular Survey of Babesia microti in Wild Rodents in Central Croatia. Vector-Borne Zoonotic Dis. 2011, 11, 81-83. [CrossRef]

73. Bajer, A.; Alsarraf, M.; Bednarska, M.; Mohallal, E.M.; Mierzejewska, E.J.; Behnke-Borowczyk, J.; Zalat, S.; Gilbert, F.; Welc-Falęciak, R. Babesia behnkei sp. nov., a novel Babesia species infecting isolated populations of Wagner's gerbil, Dipodillus dasyurus, from the Sinai Mountains, Egypt. Parasit. Vectors 2014, 7, 572. [CrossRef]

74. Krasnov, B.R.; Bordes, F.; Khokhlova, I.S.; Morand, S. Gender-biased parasitism in small mammals: Patterns, mechanisms, consequences. Mammalia 2012, 76, 1-13. [CrossRef]

75. Harrison, A.; Scantlebury, M.; Montgomery, W.I. Body mass and sex-biased parasitism in wood mice Apodemus sylvaticus. Oikos 2010, 119, 1099-1104. [CrossRef]

76. Kiffner, C.; Stanko, M.; Morand, S.; Khokhlova, I.S.; Shenbrot, G.I.; Laudisoit, A.; Leirs, H.; Hawlena, H.; Krasnov, B.R. Sex-biased parasitism is not universal: Evidence from rodent-flea associations from three biomes. Oecologia 2013, 173, 1009-1022. [CrossRef] [PubMed]

77. Khokhlova, I.S.; Spinu, M.; Krasnov, B.R.; Degen, A.A. Immune response to fleas in a wild desert rodent: Effect of parasite species, parasite burden, sex of host and host parasitological experience. J. Exp. Biol. 2004, 207, 2725-2733. [CrossRef] [PubMed]

78. Grzybek, M.; Bajer, A.; Behnke-Borowczyk, J.; Al-Sarraf, M.; Behnke, J.M. Female host sex-biased parasitism with the rodent stomach nematode Mastophorus muris in wild bank voles (Myodes z_oglareolus). Parasitol. Res. 2015, 114, 523-533. [CrossRef] [PubMed]

79. Råberg, L.; Sim, D.; Read, A.F. Disentangling genetic variation for resistance and tolerance to infectious diseases in animals. Science 2007, 318, 812-814. [CrossRef] [PubMed]

80. Råberg, L.; Graham, A.L.; Read, A.F. Decomposing health: Tolerance and resistance to parasites in animals. Philos. Trans. R. Soc. B Biol. Sci. 2009, 364, 37-49. [CrossRef] [PubMed]

81. Klein, S.L.; Flanagan, K.L. Sex differences in immune responses. Nat. Rev. Immunol. 2016, 16, 626-638. [CrossRef]

82. Colautti, R.I.; Ricciardi, A.; Grigorovich, I.A.; MacIsaac, H.J. Is invasion success explained by the enemy release hypothesis? Ecol. Lett. 2004, 7, 721-733. [CrossRef]

83. Keane, R.M.; Crawley, M.J. Exotic plant invasions and the enemy release hypothesis. Trends Ecol. Evol. 2002, 17, 164-170. [CrossRef]

84. Heger, T.; Jeschke, J.M. Enemy release hypothesis. In Invasion Biology: Hypotheses and Evidence; CABI: Wallingford, UK, 2018; pp. 92-102.

85. Prior, K.M.; Powell, T.H.Q.; Joseph, A.L.; Hellmann, J.J. Insights from community ecology into the role of enemy release in causing invasion success: The importance of native enemy effects. Biol. Invasions 2015, 17, 1283-1297. [CrossRef] 
86. Schultheis, E.H.; Berardi, A.E.; Lau, J.A. No release for the wicked: Enemy release is dynamic and not associated with invasiveness. Ecology 2015, 96, 2446-2457. [CrossRef]

87. MacLeod, C.J.; Paterson, A.M.; Tompkins, D.M.; Duncan, R.P. Parasites lost-do invaders miss the boat or drown on arrival? Ecol. Lett. 2010, 13, 516-527. [CrossRef] [PubMed]

88. Ryser-Degiorgis, M.P. Wildlife health investigations: Needs, challenges and recommendations. BMC Vet. Res. 2013, 9, 223. [CrossRef] [PubMed]

89. Sikes, R.S.; Gannon, W.L. Guidelines of the American Society of Mammalogists for the Use of Wild Mammals in Research. Available online: https://www.mammalsociety.org/articles/guidelines-americansociety-mammalogists-use-wild-mammals-research-0 (accessed on 23 January 2020).

90. Kumar, S.; Stecher, G.; Tamura, K. MEGA7: Molecular Evolutionary Genetics Analysis Version 7.0 for Bigger Datasets. Mol. Biol. Evol. 2016, 33, 1870-1874. [CrossRef] [PubMed]

(C) 2020 by the authors. Licensee MDPI, Basel, Switzerland. This article is an open access article distributed under the terms and conditions of the Creative Commons Attribution (CC BY) license (http://creativecommons.org/licenses/by/4.0/). 